\title{
Sermaye Şirketlerinin Özkaynaklarının Korunmasına Yönelik Türk Ticaret Kanunu Geçici M 13 ile Kabul Edilen COVID-19 Önlemleri
}

\begin{abstract}
Hamdi Pınar* (1), S. Özlem Türkoğlu** (), Esra Tutulmaz ${ }^{* * *}$ (1)
Öz

Geçtiğimiz aylarda tüm dünyayı etkisi altına alan COVID-19 salgınının ülkemizdeki ekonomik hayata olumsuz etkilerinin önlenmesi amacıyla birçok kanuni değişiklik yapılmıştr. Bu kapsamda ihtiyatılıık politikası gereği TTK Geçici $m$ 13 düzenlemesi de kabul edilmiştir. Bu düzenlemenin amacı salgının olumsuz etkilerinin en üst seviyede olacağının öngörüldüğü dönem için sermaye şirketlerinin özkaynaklarııı şirket bünyesinde tutulmasıdır. Düzenleme ile ülkemizdeki sermaye şirketlerinin COVID-19 salgını dönemini en az zararla atlatarak devamlılığının sağlanması hedeflenmiştir. Bu amaca ulaşmak için belli bir süre ile sınırlı olmak üzere 2019 yııı net dönem kârının en fazla \%25'inin dağıtlabileceği, geçmiş yıl kâr payları ile serbest yedek akçelerin dağıttlamayacağı ve kâr payı avans dağıtım yetkisi verilemeyeceği kuralı getirilmiştir. Hükmün, yürürlüğe giriş ve yürürlükte kalacağı tarih dikkate alındığında, getirdiği sınıllama, genel kurul kararlarının geçerliliği ve icrasına ilişkin Türk hukukunda yeni tartşmaları başlatmıştr. Bu çalışmamızda Geçici m 13 hükmünde yer alan temel kavramlar ve hükmün kapsamı ile uygulama alanı tespit edildikten sonra, sermayenin korunması ilkesi ve hükme aykırı genel kurul kararları sebebiyle ortaya çıkacak muhtemel sorunlar ve bunlara ilişkin görüşlerimiz inceleme konusu yapılmıştı.
\end{abstract}

\section{Anahtar Kelimeler}

COVID-19, Sermaye şirketi, Kâr payı, Sermayenin korunması ilkesi, Butlan

COVID-19 Measures Adopted Under the Provisional Article 13 of the Turkish Commercial Code for the Protection of the Equity of Stock Corporations

\begin{abstract}
Several legal amendments regarding the economic life in Turkey have been made to prevent the negative impacts of the coronavirus disease 2019 (COVID-19). The Provisional Article 13 of the Turkish Commercial Code (TCC) has been adopted due to the precautionary principle. This regulation aims to keep the equity of stock corporations within the company during this epidemic. The provision aims to ensure the continuity of the stock corporations in our country by overcoming the COVID-19 pandemic with minimum damage. According to the provision, for a certain period of time, the corporations can only distribute their net profits for the fiscal year of 2019 up to $25 \%$, cannot subject the previous years' dividends and distributable reserves to distribution, and cannot give authority to their governing bodies to distribute advance dividend. The enforcement date of the provision has initiated new discussions in Turkish law about the validity and execution of general assembly resolutions. This study examines the principle of capital maintenance and possible problems regarding the outcome of the general assembly resolution about distribution after determining the basic concepts, scope, and execution area of the TCC's Provisional Article 13.
\end{abstract}

\section{Keywords}

COVID-19, Stock corporation, Dividend, Principle of capital maintenance, Invalidity

* Sorumlu Yazar: Hamdi Pınar (Dr. Öğr. Üyesi) Bilkent Üniversitesi, Hukuk Fakültesi, Ticaret Hukuku Anabilim Dalı, Ankara, Türkiye. E-posta: hpinar@bilkent.edu.tr ORCID: 0000-0002-3864-3736

** S. Özlem Türkoğlu (Avukat), Ankara Barosu, Ankara, Türkiye. E-posta: ozlemturkoglu@outlook.com ORCID: 0000-0002-4300-9422

*** Esra Tutulmaz (Stj Avukat), Ankara Barosu, Ankara, Türkiye. E-posta: esratutulmaz@gmail.com ORCID: 0000-0003-4499-2964

Atrf: Pinar H, Turkoglu SO ve Tutulmaz E, "Sermaye Şirketlerinin Özkaynaklarının Korunmasına Yönelik Türk Ticaret Kanunu Geçici M 13 ile Kabul Edilen COVID-19 Önlemleri” (2020) 78(2) İstanbul Hukuk Mecmuası 579. https://doi.org/10.26650/mecmua.2020.78.2.0012 


\section{Extended Summary}

Provisional Article 13 has been added to the TCC in the context of measures against the negative impacts of the COVID-19 pandemic on business life, aiming to prevent the potential need for financing and to maintain strong capital in cash and ensure continuity for stock corporations.

The distribution of distributable reserves and retained earnings of stock corporations is prohibited for the duration in which the Provisional Article 13 is effective. A maximum of $25 \%$ of the net profit of the fiscal year of 2019 can be distributed, and governing bodies cannot be given the authority to distribute dividend advances. The scope of the Provisional Article 13 that is the subject of our review, its application, and our perspectives on the challenges that may arise in the implementation of this provision are as follows.

The joint stock companies, limited companies, and commandite companies whose capital is divided into shares are subject to this provision. The provision limits the distribution of dividend, distributable reserves, and advance dividend. However, Provisional Article 13 and the Communiqué set out companies that will not be subject to these distribution restrictions.

The publication and enforcement date of Provisional Article 13 is April 17, 2020, and the first paragraph of this article shall be applied in respect of corporations that have not yet taken general assembly resolution regarding distribution by April 17, 2020 .

The second paragraph of the article includes corporations that have decided to distribute for the period of 2019 but have not distributed fully. The article shall remain in force until September 30, 2020, and the President shall be authorized to extend and contract this period by 3 months. (Note: The period has been extended for 3 months.)

Therefore, Provisional Article 13 will not have any effect with respect to these transactions if the general assembly resolution taken before April 17, 2020, is executed fully. If the distribution is made partially as of April 17, 2020, remaining payments for the portion exceeding $25 \%$ of the net profit for the fiscal year of 2019 will be deferred until Provisional Article 13 cease to have effect. Moreover, the advance payments that have not yet been distributed will be deferred in the same way if the general assembly resolution authorizes the distribution of advanced dividend payments.

The lapse of time on the claim of deferred payments shall cease during the enforcement period of Provisional Article 13, and no interest shall be claimed for deferred payments. 
The legal basis of the sanctions relating to the general assembly resolutions that exceed the limit regulated by Provisional Article 13 and taken after the date of April 17, 2020, is controversial. Because Provisional Article 13 is a provision concerning the principle of maintenance of capital, we believe that whether the resolutions are in breach of this provision or are invalid within the framework of Article 447 of the TCC should be examined.

According to our opinion, a general assembly resolution taken after April 17, 2020, and only partially in breach of the Provisional Article 13 of the TCC should be subject to partial invalidity. Such approach would conform with the teleological interpretation of the relevant provision and to the procedural economy.

At a general meeting after April 17, 2020, it is also possible to decide on the distribution of $25 \%$ of the net profit immediately and the distribution of extra dividend after Provisional Article 13 will cease to have effect. We believe that following the constitutional interpretation, no part of such resolution shall be subject to invalidity.

Dividend shares that are distributed to the board of directors are not directly regulated in Provisional Article 13. However, the main purpose of the provision is not to distribute more than $25 \%$ of the company's net profit for the enforcement period. We believe that dividend shares should be added to the scope of Provisional Article 13 , considering that dividend shares are distributed from the net profit.

Prohibition of borrowing from the company for shareholders serves for the principal of capital maintenance, which makes the absence of its mention in Provisional Article 13 a deficiency. Following TCC Article 385, all shareholders who do not owe due capital debt will be able to become indebted to the corporation if the profit of the corporation together with the distributable reserves covers the losses of the previous year. In this way, the Provisional Article 13 will be eliminated, and it is possible to cash out of the corporation without any limit during the period.

In case an unlawful resolution is adopted by the general assembly, the governing bodies that execute the illegal resolution will be held responsible. Therefore, the governing bodies should avoid distributing net profits that exceed $25 \%$ in distributable reserves and/or advance dividend, contrary to the Provisional Article 13. In this case, if it is needed, the governing bodies are obliged to apply to the court and request an invalidity declaration of the regulations that are against the provision. 


\section{Sermaye Şirketlerinin Özkaynaklarının Korunmasına Yönelik Türk Ticaret Kanunu Geçici M 13 ile Kabul Edilen COVID-19 Önlemleri}

\section{Giriş}

Çin'de başlayıp tüm dünyaya yayılan COVID-19 salgını kaynaklı Türkiye'deki ilk vakanın 11.03.2020 tarihinde duyurulması üzerine kişisel izolasyonun yanında idari kararlar ve yasal düzenlemeler yoluyla da çeşitli önlemler alınmıştır. Özellikle kalabalık ortamların virüsün yayılmasını kolaylaştırması nedeniyle birçok işyeri çalışma sistemini değiştirmiş; kimi evden çalışma yöntemine geçmiş kimi ise vardiyalı çalışma sistemini benimsemiştir. Sosyal hayatın sınırlanması, pek çok şehir için uygulanan seyahat ve sokağa çıkma kısıtlamaları ekonomiyi de olumsuz etkilemiş ve sonuçta birçok işyeri çalışanlarını ücretsiz izne çıkarmıştır. Sürecin devamında çalışanların işlerine son verilmeye başlanmasıyla oluşacak işsizliğin önüne geçmek amacıyla fesih yasağına ilişkin düzenleme getirilmiştir.

Ekonomide meydana gelen endişe verici gelişmeler sonucunda sermaye şirketlerinin özkaynaklarının korunması amacıyla TC Ticaret Bakanlığınca (Bakanlık) Türkiye Odalar ve Borsalar Birliği’ne (TOBB) 31.03.2020 tarihinde bir yazı gönderilmiştir. TOBB ise ilgili yazı içeriğine ilişkin tüm oda ve borsalara gerekli bilgilendirmeyi 01.04.2020 tarihinde yapmıştır ${ }^{1}$. Duyuru yazısında Bakanlığın özkaynakların korunmasına atfettiği önemin altı çizilmiş ve şu ifadelerin şirketlere duyurulması talep edilmiştir:

"kamunun iştirak olan şirketler hariç olmak üzere, sermaye şirketlerinin 2019 yll hesap dönemine ilişskin olarak bu yıl gerçekleştirilecek genel kurul toplantılarında gündeme alınacak nakit kâr payı dağıtımı kararlarında, geçmiş yıl kârlarının dă̆ıtıma konu edilmemesi ve dağıtım tutarının 2019 yılı net dönem kârının \%25'ini aşmaması ile yönetim kuruluna kâr payı avansı dă̆ıtımı yetkisi verilmemesi..."

Sermaye şirketlerinde özkaynakların korunmasına yönelik kanuni düzenleme öncesi yapılan bu duyuru ile Bakanlık, kamu iştiraki olan şirketleri istisna tutup tüm sermaye şirketlerinin kâr payı dağıtımına üç önemli sınırlama getirmiştir. Bakanlığın TOBB aracılığıyla duyurduğu ilgili sınırlamaların hukuki dayanağının Anonim Şirketlerin Genel Kurul Toplantılarının Usul ve Esasları ile Bu Toplantılarda Bulunacak Ticaret Bakanlığı Temsilcileri Hakkında Yönetmelik² m 13/5 olduğu belirtilmiştir. Ancak genel kurulun kâr payı dağıtımına ilişkin devredilemez yetkisi ve serbest iradesinin 6102 sayılı Türk Ticaret Kanunu (TTK) m 408/2 ile hüküm altına alınması karşısında Bakanlığın ilgili yazısının normlar hiyerarşisinde bağlayıcı

\footnotetext{
İlgili duyuru metni için bkz https://itb.org.tr/img/userfiles/files/Sermaye $\% 20 \%$ C5\% 0 Eirketlerinin $\% 20$ Kar $\% 20$ Da\%C4\%9F\%C4\%B1t\%C4\%B1m\%C4\%B1\%20hk.pdf?v=1591684129831 Erişim Tarihi 11 Mayıs 2020.

28.11.2012 tarihli ve 28481 sayılı Resmî Gazete'de yayımlanmıştır.
} 
olmayan bir tavsiyeden öteye geçemeyeceği sonucuna ulaşılmıştır ${ }^{3}$ Dolayısıyla söz konusu duyuruda yer alan taleplerin gündeme eklenmesi gerektiği fakat Bakanlık duyurusu ile genel kurulun iradesinin bağlanmasının hukuken mümkün olmaması sebebiyle ilgili genel kurulda aksine kararlar alınması halinde duyurunun genel kurul kararının geçerliliğini etkilemeyeceği tartışmasızdır.

Bakanlık yazısına müteakiben TOBB tarafından yapılan duyurunun hukuken bağlayıcı olup olmadığı hakkındaki tartışmaya son vermek amacıyla ilgili konuda 7244 say1lı Yeni Koronavirüs -COVID-19- Salgınının Ekonomik ve Sosyal Hayata Etkilerinin Azaltılması Hakkında Kanun ve Bazı Kanunlarda Değişiklik Yapılmasına Dair Kanun ${ }^{4}$ (7244 sayılı Kanun) ile TTK'ya Geçici m 13 hükmü eklenmiştir. $\mathrm{Bu}$ çalışmada Geçici 13. maddenin amacı, kapsamı ve uygulaması incelenecek, sermaye şirketlerinin genel kurul kararlarına ilişkin ilgili düzenleme bağlamında ortaya çıkması muhtemel sorunlar ele alınarak uygulamaya yol gösterici nitelikteki değerlendirmemizden sonra yönetim organı üyelerinin sorumluluğunun doğup doğmayacağı tartışılacaktır.

\section{Kanuni Düzenleme - TTK Geçici m 13}

7244 sayılı Kanun m 12 ile sermaye şirketlerinin özkaynaklarının korunmasına yönelik olarak getirilen TTK Geçici m 13 şu şekildedir:

“(1) Sermaye şirketlerinde, 30/9/2020 tarihine kadar 2019 yılı net dönem kârının yalnızca yüzde yirmi beşine kadarının dağıtımına karar verilebilir, geçmiş yıl kârları ve serbest yedek akçeler dağıtıma konu edilemez, genel kurulca yönetim kuruluna kâr payı avansı dağıtımı yetkisi verilemez. Devlet, il özel idaresi, belediye, köy ile diğer kamu tüzel kişilerinin ve sermayesinin yüzde ellisinden fazlası kamuya ait fonların, doğrudan veya dolaylı olarak sermayesinin yüzde ellisinden fazlasina sahip olduğu şirketler hakkında bu fikra hükmü uygulanmaz. Bu fikrada belirtilen süreyi üç ay uzatmaya ve kısaltmaya Cumhurbaşkanı yetkilidir.

(2) Genel kurulca 2019 yılı hesap dönemine ilişkin kâr payı dağıtımı kararı alınmış ancak henüz pay sahiplerine ödeme yapılmamışsa veya kısmi ödeme yapılmıssa, 2019 yılı net

Bu konuda öğreti fikir birliği içindedir. Bkz Hamdi Pınar ve Özlem Türkoğlu, 'Sermaye Şirketlerinin Öz Kaynaklarını Korumasına İlişkin COVID-19 Önlemleri’ (Magna Hukuk, 20 Mayıs 2020) http://www.magnahukuk.com/sermayesirketlerinin-oz-kaynaklarini-korumasina-iliskin-covid-19-onlemleri/ Erişim Tarihi 20 Mayıs 2020; Serdar Karababa, 'Koronavirüs (COVID-19) Pandemisi Nedeniyle 7244 sayılı Kanun'la Türk Ticaret Kanunu'nda Yapılan Değişikliklerin Sermaye Şirketlerinde Kâr Payı Dağıtımına Etkisi' (LexperaBlog, 30 Nisan 2020) https://blog.lexpera.com.tr/koronaviruscovid-19-pandemisi-nedeniyle-7244-sayili-kanunla-turk-ticaret-kanununda-yapilan-degisikliklerin-sermaye-sirketlerindekar-payi-dagitimina-etkisi/ Erişim Tarihi 28 Mayıs 2020; Murat Yusuf Akın, 'Murat Yusuf Akın: Ticaret Bakanlığının 31.03.2020 tarihli Kâr Payı Dağıtımına İlişsin Yazısı Üzerine Düşünceler' (Ticaret Kanunu.Net, 9 Nisan 2020) http://www. ticaretkanunu.net/murat-yusuf-akin-ticaret-bakanliginin-31-03-2020-tarihli-kar-payi-dagitimina-iliskin-yazisi-uzerinedusunceler/ Erişim Tarihi 20 Nisan 2020; Bilge Aytuğar, 'Anonim Şirketlerde Kar Payı ve Kar Payı Avansı Dağıtımı Hakkında 7244 Sayılı Kanun ile Öngörülen Tedbirler’(2020) İnönü Üniversitesi Hukuk Fakültesi Dergisi 11(2) 402.

17.04.2020 tarihli ve 31102 sayılı Resmî Gazete'de yayımlanmıştır. 18.09.2020 tarihli ve 31248 sayılı Resmi Gazete'de yayımlanan Cumhurbaşkanı Kararı ile TTK Geçici m 13’te belirtilen süre üç ay uzatılmıştır. Bu çalışma söz konusu karardan önce tamamlanmış olduğundan çalışmamızın devamında Geçici m 13'ün uygulanacağı son tarih 30.09.2020 olarak ifade edilmiştir. 
dönem kârının yüzde yirmi beşini aşan kısma ilişskin ödemeler birinci fikrada belirtilen sürenin sonuna kadar ertelenir.

(3) Bu maddenin kapsamına giren sermaye şirketlerine ilişkin istisnalar ile uygulamaya dair usul ve esasları belirlemeye, Hazine ve Maliye Bakanlığının görüşünü almak suretiyle Ticaret Bakanlı̆̆ yetkilidir."

6102 Sayılı Türk Ticaret Kanununun Geçici 13 üncü Maddesinin Uygulanmasına İlişkin Usul ve Esaslar Hakkında Tebliğ ${ }^{5}$ (Tebliğ) yürürlüğe girmiş ve söz konusu düzenlemeye ilişkin çeşitli istisnalar getirilmiştir.

\section{A. Düzenlemenin Amacı}

7244 sayılı Kanun ile düzenlenen TTK Geçici m 13 temel anlamda COVID-19 salgınının ekonomi alanında oluşturduğu belirsizliğin doğurabileceği olumsuz etkilere karşı bir önlem olarak öngörülmüştür. Nitekim ilgili madde gerekçesinde COVID-19'un toplum sağlığı yanında ekonomik hayat için de oluşturduğu ciddi tehditten bahsedilmiş ve düzenlemenin salgının ekonomik faaliyetler üzerindeki olumsuz etkilerinin bertaraf edilebilmesi amacıyla bir tedbir niteliğinde olduğuna işaret edilmiştir. Söz konusu hükmün gerekçesinin tam metni şöyledir:

"Yeni koronavirüs (COVID-19), toplum sağlı̆̆ına olduğu kadar ekonomik hayata ciddi bir tehdit oluşturmaktadır. Salgının ekonomik faaliyetler üzerindeki olumsuz etkilerinin bertaraf edilebilmesi amacıyla çeşitli tedbir programları uygulamaya konulmuştur.

Ekonomik faaliyetlerin yavaşlamast, sınırların kapatılması, ekonominin hem arz hem de talep tarafinda ortaya çıkan belirsizlikler sebebiyle salgının toplum sağlı̆̆ı ve ekonomi üzerindeki etkileri henüz net olarak ortaya konulamamaktadır.

Bu çerçevede, ihtiyatlılık politikası gereği olarak, şirket kaynaklarının nakit kâr dağıtımı yapılmak suretiyle azaltılmaması, şirketlerimizin mevcut özkaynak yapılarının korunması ve ilave finansman ihtiyacının doğmaması amactyla madde ile; 30/09/2020 tarihine kadar yapılacak kâr dă̆ıtımına ilişkin düzenleme yapılmaktadır6."

Hükmün gerekçesinden de anlaşılabileceği üzere yapılan düzenlemenin üç amacı olup bunların tamamı temelde "ihtiyatlılık politikası"na dayanmaktadır. Söz konusu amaçlar; "şirket kaynaklarının nakit kâr dă̆ıtımı yapılmak suretiyle azaltılmaması, şirketlerimizin mevcut özkaynak yapılarının korunması ve ilave finansman ihtiyacının doğmaması " olarak ifade edilmiştir. Bu düzenleme ile COVID-19 salgınının ekonomik etkilerinin ne kadar süreceğinin bilinememesi sebebiyle sermaye şirketlerinin uzun vadede ekonomik sıkıntılar yaşamasının önüne geçilmek istenmiştir. Zira 16.03.2020 itibariyle COVID-19'la mücadele kapsamında ekonomik sonuç doğurabilecek önlemler kademeli olarak alınmaya başlanmış olup 7244 sayılı Kanunun yürürlük

17.05.2020 tarihli ve 31130 sayılı Resmî Gazete'de yayımlanmıştır.

67244 sayılı Kanun gerekçesinin tam metni için bkz TBMM Sıra Sayısı: 21312 https://www.tbmm.gov.tr/sirasayi/donem27/ yil01/ss213.pdf Erişim Tarihi 12 Haziran 2020. 
tarihi itibariyle salgının etki alanı ve süresine ilişkin belirsizlik devam etmekteydi. Dolayısıyla Geçici m 13 hükmü ile şirketlerin özkaynaklarının ekonominin olumsuz gidişatından mümkün olduğunca az etkilenmesi ve ilerleyen zamanlarda şirketlerin borca batıklık, iflas gibi durumlarla karşılaşmasının önüne geçilmesi hedeflenmiştir7.

\section{B. Geçici m 13 Düzenlemesinin Kapsamı}

\section{Kişi Bakımından Kapsamı}

TTK Geçici m 13'ün kişi yönünden kapsamı ilk fikrada ortaya konulmuştur. Buna göre hükmün muhatabı sadece sermaye şirketleridir. TTK m 124/2'ye göre sermaye şirketi, anonim, limited ve sermayesi paylara bölünmüş komandit şirkettir. Dolayısıyla Geçici m 13 kapsamına bu üç şirket tipi girmektedir.

TTK Geçici 13. maddenin ilk fikrasının ilk cümlesinde "genel kurulca yönetim kuruluna kâr payı avansı dağıtım yetkisi" verilemeyeceği düzenlenmiştir. Hükmün lafżndan, yönetim kurulunun anonim şirketin yönetim organı olması nedeniyle kâr payı avansı dağıtımı için yetki verilemeyeceğine ilişkin düzenlemenin yalnızca anonim şirketler bağlamında getirildiği gibi bir anlam çıkarılabilecektir. Ancak Geçici m 13'ün TTK'daki diğer maddelerle ilişkisi (m 124/2), yeni hükmün gerekçesi ve amacı bir arada değerlendirildiğinde sermaye şirketlerinin tamamını kapsadığı tartışmasızdır. Nitekim Tebliğ hükümlerinde "yönetim kurulu" kavramı yerine "yönetim organı"

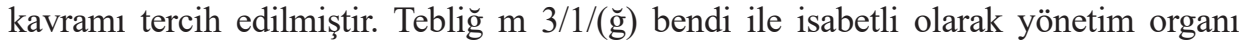
kavramı diğer sermaye şirketlerinin yöneticilerini de kapsar şekilde tanımlanmıştır. $\mathrm{Bu}$ tanıma göre sermaye şirketlerinin yönetim organlarına genel kurulun kâr payı avansı dağııımı için yetki veremeyeceğine ilişkin düzenleme yalnızca anonim şirketlerdeki yönetim kurulları için değil limited şirketlerde müdürler ve sermayesi paylara bölünmüş komandit şirketlerde yöneticiler için de geçerli olacaktır.

Söz konusu düzenleme temelde 2020 yılında henüz dağıtım kararı almayan sermaye şirketlerini ve ikinci fikra gereğince 2019 yılı dönemine ilişkin dağıtım kararı almış ancak henüz tamamen dağıtım yapmamış şirketleri de kapsamaktadır.

\footnotetext{
Hükmün tartışıldığı Plan Bütçe Komisyonunda sunulan bir muhalefet şerhinde, getirilen bu sınırlama ile dağıtılan kâr payı üzerinden devlete ödenecek verginin de zorunlu olarak azalacağı, bu kapsamda yaklaşık olarak stopaj sebebiyle 4,5 milyar TL, gelir vergisi sebebiyle de 6 milyar TL olmak üzere toplam 10,5 milyar TL gibi bir gelir kaybıyla karşı karșıya kalınacağı; hükmün şirketleri zorunlu olarak tasarruf etmeye yöneltirken dağıtılmayan kârın sonuçta toplam talepten çekilen bir harcama olduğu, bu gelirlerin dağıtılması halinde toplam talebe sağlayacağı olumlu katkının göz önüne alınması gerektiği ifade edilmiştir. Bkz TBMM Sıra Sayısı: 213 62-63 https://www.tbmm.gov.tr/sirasayi/donem27/yil01/ss213.pdf Erişim Tarihi 12 Haziran 2020
} 
Öte yandan düzenlemenin birinci fikrasının son cümlesinde hükmün istisnaları devlet, il özel idaresi, belediye, köy ile diğer kamu tüzel kişilerinin ve sermayesinin yüzde ellisinden fazlası kamuya ait fonların doğrudan veya dolaylı olarak sermayesinin yüzde ellisinden fazlasına sahip olduğu şirketler ${ }^{8}$ olarak sayılmıştır.

\section{Konu Bakımından Kapsamı}

Getirilen bu düzenleme ile sermaye şirketlerinin 2019 yılı hesap dönemine ilişkin 2020 yılında yapılacak genel kurul toplantılarında;

(1) 2019 net dönem kârının en fazla \%25'inin dağıtılabileceği,

(2) Geçmiş y1l kârlarının (2018 ve öncesi) ve serbest yedek akçelerin dağııtılamayacağı,

(3) Yönetim organına kâr payı avansı dağıtma yetkisi verilemeyeceği

hüküm altına alınmıştır.

Söz konusu hükümde açıkça kâr payı, serbest yedek akçe ve kâr payı avansı dağıtımından bahsedilmiş olsa da hükmün şirketlerden nakit çıkışını ihtiyatlılık politikası gereği sınırlandırma amacı göz önünde bulundurulduğunda bahsi geçen sınırlamalar yanında kazanç payı dağıtımı ve ortakların şirketlere borçlanması hallerinin de değerlendirilmesi gerekmektedir.

\section{a. Kâr Payı}

TTK Geçici m 13 ile düzenlenen temel husus 2019 yılı net dönem kârının dağıtımına ilişkin getirilen sınırlamadır. Hükmün yürürlük tarihi olan 17.04.2020 sonrası yapılan genel kurul toplantılarında 2019 net dönem kârının en fazla \%25'inin dağıtılabileceği ve geçmiş yıl kârlarının dağıtılamayacağı düzenlenmiştir. Bu düzenlemenin kapsamı ve amacının anlaşılması için kâr ve kâr payı kavramlarının tanımı ve hukuki niteliği incelenmelidir.

Sermaye şirketleri kanunen yasaklanmamış her türlü ekonomik amaç ve konu için kurulabilmekte olup ${ }^{9}$ nihai amaçları kâr elde etmek ve dağıtmaktır ${ }^{10}$. Genel anlamıyla "bir ticaret şirketi bakımından kâr, yıllık hesap devresi içinde şirket faaliyeti sonunda

\footnotetext{
8 Örnek vermek gerekirse varlık fonu portföyünde bulunan şirketlerden fon sahiplik oranına göre Ziraat Bankası (\%100), Halkbank (\%75,3), Botaş (\%100), Eti Maden (\%100), Türksat (\%100) Geçici m 13/3’te yer alan istisna kapsamında sayılırken; Vakıfbank (\%36), Türk Hava Yolları (\%49,12), Türk Denizcilik İşletmeleri $(\% 49)$, Türk Telekom $(\% 6,68)$ ise istisna kapsamında değildir. Bkz https://www.tvf.com.tr/portfoyumuz Erişim Tarihi 12 Haziran 2020.

9 İlgili hükümler için bkz TTK m 331, m 573/3, m 565/2.

10 Reha Poroy, Ünal Tekinalp ve Ersin Çamoğlu, Ortaklıklar Hukuku I (Güncellenmiş, Yeniden Yazılmış 14. Bası, Vedat 2019) 696; Oğuz İmregün, 'Anonim Ortaklıkta Pay Sahibinin Kar Payı (Temettü) Hakkı' Prof. Dr. Ömer Teoman'a 55. Yaş Günü Armağanı C 12002 413; Yüksel Bilgin, Anonim Ortaklıklarda Kar Dağıtımı ve Kara Katılan Kişiler (Ankara İktisadi ve Ticari İlimler Akademisi 1982) 12; Güzin Üçışık ve Aydın Çelik, Anonim Ortaklıkta Finansal Tablolar Yedek Akçeler ve Kar Dă̆ıtımı (On İki Levha 2018) 291.
} 
o yılın kâr ve zarar hesabının kâr bakiyesi vermesi halinde şirket bilançosunun pasif tablosuna yazllan ve genellikle kanun ve esas sözleşme hükümlerine göre ortaklara dağıtılmaya tahsis olunan kalemdir. Ortak açısından kâr ise ortağın servetine eklenecek nakdi bir kazançtır."11.

TTK Geçici m 13 hükmüne ilişkin yayımlanan Tebliğ’de de kâr pay1" "Net dönem kârı veya serbest yedek akçeler üzerinden ortaklara ve kâra katılan diğer kimselere genel kurulca dağıtılmasına karar verilen tutar" olarak tanımlanmıştır ${ }^{13}$.

Ortakların kâr payı hakkını düzenleyen TTK m 507'ye göre her pay sahibi, kanun ve esas sözleşme hükümlerine göre pay sahiplerine dağıtılması kararlaştırılmış net dönem kârına, payı oranında katılma hakkını haizdir. Net dönem kârı ise TTK' da ve ikincil mevzuatta tanımlanmamıştır. Fakat genel olarak yıllık kârdan geçmiş yıllara ait zararların ve şirketin ödemekle yükümlü olduğu vergiler ve mali yükümlülüklerin düşülmesinden sonra kalan tutar net dönem kârını ifade etmektedir ${ }^{14}$. Dolayısıyla dağıtılabilir kâr, son hesap döneminde elde edilen net dönem kârı, önceki dönemden elde edilen kârdan dağıtılmayan kısımlar, kâr dağıtımı için ayrılan özel yedek akçeler, belli bir amaca tahsis edilmeyen yedek akçeler ve ihtiyari yedek akçeden oluşan kârdır ${ }^{15}$.

Kâr payı hakkı, ortakların sermaye için şirkete yaptıkları ödeme ile orantılı olarak sahip oldukları, paya bağlı mali haklardandır ${ }^{16}$. Bu hak ancak genel kurul tarafindan kâr dağıtımı kararı alınması halinde pay sahibi açısından bir alacak hakkına dönüşebildiği için şarta bağlı alacak hakkı niteliğindedir ${ }^{17}$. Kâr elde etme ve dağıtma amacı esas sözleşmelerde yer almasa dahi emredici nitelikteki TTK m 331'den kaynaklanır. Dolayısıyla söz konusu amaçtan doğan kâr payı hakkı vazgeçilemez bir haktır $^{18}$. Zira vazgeçilmez haklar ancak sermaye şirketinin temel yapısı gereği oluşan,

${ }_{11}$ Aslı E. Gürbüz Usluel, Anonim Şirketlerde Pay Sahibinin Kâr Payı Alma Hakkı (Banka ve Ticaret Hukuku Araştırma Enstitüsü 2016) 10.

12 Kâr payının ortaklar tarafından şirkete ödenen sermayenin semeresi olduğu ifade edilmektedir. Bkz İmregün (n 10) 414 vd; Bilgin (n 10) 36.

13 Kâr Payı Tebliği m 3/1/(f) bendinde kâr payını "Net dönem kârı veya kâr dağıtımına konu edilebilecek kaynaklar üzerinden ortaklara ve kâra katılan diğer kimselere genel kurulca dağıtılmasına karar verilen tutar" olarak tanımlamıştır. Tebliğ metni için bkz 23.01.2014 tarihli ve 28891 sayılı Resmî Gazete. Konuya ilişkin ayrıntılı bilgi için bkz Bilgin (n 10) 53 vd.

14 Poroy, Tekinalp ve Çamoğlu (n 10) 697; Veliye Yanlı, 'Yeni Ticaret Kanunu ve Anonim Şirketlerde Kâr Dağıtımı' (2014), Banka ve Ticaret Hukuku Dergisi C 30 S1 7; İmregün (n 10) 417; Işı Özer, Türk ve Yabancl Hukuk Sistemlerinde Anonim Şirket Yöneticilerinin Mali Hakları (Adalet 2013) 232. Net dönem kârının tespitine ilişkin ayrıntılı açıklamalar için bkz Üçışık ve Çelik, (n 10) 206-217; Erdem Ateşağaoğlu, Vergi Hukuku Bakımından Anonim Şirketlerde Kâr Payı Dağıtımı (On İki Levha 2012) 42 vd.

15 Gürbüz Usluel (n 11) 14; Bilgin (n 10) 17.

16 Gürbüz Usluel (n 11) 90; Ateşağaoğlu (n 14) 24.

17 Hasan Pulaşlı, Şirketler Hukuku Genel Esaslar (Adalet 2020) 569; Rıza Ayhan, Hayrettin Çağlar ve Mehmet Özdamar, Şirketler Hukuku Genel Esaslar (2. Bask1, Yetkin 2020) 428; Üçışık ve Çelik, (n 10) 294; Bilgin (n 10) 38; Özer (n 14) 339.

18 Poroy, Tekinalp ve Çamoğlu (n 10) 696; Hasan Karslığlu, 'Anonim Şirketlerde Kâr Payının Hesaplanması ve Dağıtım İlkeleri' (2019) Ankara Barosu Dergisi C 77 S 3 190; Ünal Tekinalp, Sermaye Ortaklıklarının Yeni Hukuku (Değişiklikler ve İkincil Düzenlemelerle Güncelleştirilmiş 4. Bası, Vedat 2015) 354; İmregün (n 10) 428; Üçışık ve Çelik, (n 10) 298; Özer (n 14) 242. Ateşağaoğlu (n 14) 26-27. Kâr payının hukuki niteliğine ilişkin olarak ağırlıklı görüş vazgeçilmez bir hak olduğu yönündedir. Bu konuya ilişkin tartışmalar ve aksi görüş için bkz Gürbüz Usluel (n 11) 96-105; Aytuğar, (n 3) 398-399. 
kanunda sınırlanabilen ve eşitlik ilkesine tabi haklardır ${ }^{19}$. Uygulamada da pek çok Yargıtay kararında kâr payı hakkının vazgeçilmez niteliğinden söz edilmektedir ${ }^{20}$.

Kâr payı genel kurul kararına dayalı olarak dağıtılmayabileceği için söz konusu hak mutlak şekilde müktesep hak niteliği taşımaz ${ }^{21}$. Zira müktesep hak sınırlandırılması, değiştirilmesi, ortadan kaldırılması için pay sahipleri ve temsilcilerinin oy birliğinin arandığı haklardır 22 . Oysa kâr payı dağıtımına ilişkin genel kurul kararı aksi esas sözleşmede kararlaştırılmadıkça TTK m 418/1 uyarınca oybirliği aranmaksızın alınmaktadır. Uygulamada da Yargıtay’ın kâr payının müktesep hak olma kuralının mutlak olmadığı, uzun vadede daha yüksek ve istikrarlı kâr payı dağıtılmasını sağlamak gibi bir haklı nedenle net kârın saklı tutulan oranının dahi olağanüstü yedek akçelere ayrılmasının mümkün olduğu yönünde kararları mevcuttur ${ }^{23}$.

Genel anlamda şirketlerin mutlak olarak kâr dağıtımı zorunluluğunun olmadığ1, şirket menfaati ile pay sahibi menfaati arasında denge sağlanması şartıyla, haklı nedenle kâr dağıtılmamasının ve yedek akçe olarak şirkette tutulmasının da mümkün olabileceği sonucuna ulaşılabilecektir ${ }^{24}$.

TTK m 509/2'ye göre kural olarak kâr payı dağıtımı yalnızca net dönem kârı ve serbest yedek akçelerden gerçekleştirilebilir. Ancak TTK Geçici m 13'ün açık olan lafzından dolayı kâr payı dağıtımında serbest yedek akçe kullanımı geçici bir süre için tamamen yasaklanmıştır. Bunun sonucu olarak Geçici m 13 yürürlükte kaldığı sürece kâr payı dağıtımı yalnızca net dönem kârından yapılabilecek olup bu dağıtım miktarı da söz konusu kârın \%25'i ile sınırlandırılmıştır. Netice itibariyle TTK m 509/2 hükmünün serbest yedek akçelere ilişkin kısmı Geçici m 13 sebebiyle geçici bir süre ile uygulanamayacaktır.

\section{b. Kâr Payı Avansı}

TTK m 509/3 hükmünde anonim şirketlerde kâr payı avansının Sermaye Piyasası Kanununa tabi olmayan şirketlerde, Bakanlığın bir tebliği ile düzenleneceği ifade edilmiş, TTK'nın yürürlük tarihinden kısa bir süre sonra Kâr Payı Avansı Dağıtımı

\footnotetext{
9 Poroy, Tekinalp ve Çamoğlu (n 10) 684.

20 Yargıtay Hukuk Genel Kurulu'nun 17.01.2018 tarihli, 2017/11-2874 E ve 2018/37 K sayılı kararı; Yargıtay 11. Hukuk Dairesi'nin 17.03.2016 tarihli, 2015/6354 E ve 2016/3021 K sayılı kararı (Kazancı veri taban1).

21 Tekinalp (n 18) 354; Gürbüz Usluel (n 11) 105; Senar Çağırgan Tuncer ve Yasin Ulusoy, 'Yedek Akçeler' (2017) DEÜ Hukuk Fakültesi Dergisi Prof. Dr. Şeref Ertaş'a Armağan C 19 Özel Sayı 1992; Özer (n 14) 242; Üçışık ve Çelik, (n 10) 296-297; Aytuğar (n 3) 399.

22 İsmail Kırca, Feyzan Hayal Şehirali Çelik ve Çağlar Manavgat, Anonim Şirketler Hukuku (Cilt 2/2, Banka ve Ticaret Hukuku Araştırma Enstitüsü 2016) 31.

23 Yargıtay 11. Hukuk Dairesi'nin 10.2.2005 tarihli, 2004/2649 E ve 2005/990 K sayılı kararı (Kazancı veri tabanı).

24 Yanlı (n 14) 27; M. Halil Çonkar, 'Halka Açık Anonim Ortaklıklarda Kâr Payı Hakkına İlişkin Bazı Meseleler' (2017) İstanbul Hukuk Fakültesi Mecmuası C 75 S 2 665, 666; Çağırgan Tuncer ve Ulusoy (n 21) 1980. Genel kurulda kâr dağıtımı hakkında karar alınması için işletmenin likidite durumu, yatırımları nedeniyle fon ihtiyacı, ileri vadeli borçlanmaları gibi hususları değerlendirmesi gerektiğine ilişkin ayrıntılı açıklamalar için bkz Ateşağaoğlu (n 14) 33-35.
} 
Hakkında Tebliğg ${ }^{25}$ (Avans Dă̆ıtımı Tebliğ) çıkarılmıştır. TTK m 644'teki atıf dolayısıyla bu hüküm, limited şirketler için de uygulanacaktır.

Avans Dağıtımı Tebliğinde sermaye şirketleri açısından kâr payı avansı dağıtımına ilişkin usul ve esaslar yer almış ve m 4/1/(c) bendinde kâr payı avansı, kâr payından mahsup edilmek üzere ara dönem finansal tablolara göre oluşan kârlar üzerinden bu tebliğ hükümlerine göre hesaplanan tutar olarak tanımlanmıştır. Bu tebliğin 8 . maddesine göre kâr payı avansı yalnızca ortaklara payları oranında ödenmekte, ortaklar dışında kâra katılması öngörülen diğer kimseler ise kâr payı avansından yararlanamamaktadır.

Kâr payı avansı ödemesi için gereken şartlar şirketin kâr etmiş olması, bu hususta genel kurulda karar alınması ve Avans Dağıtımı Tebliği m 7' de sayılan tutarların indirilmesidir²6.

Kâr payı avansı, söz konusu avansın dağıtılacağı hesap dönemi içinde yapılacak genel kurul toplantısında karara bağlanır. Bu konuda TTK' da açık hüküm bulunmamakla beraber genel kurulun devredilemez yetkilerinin düzenlendiği m 408/2/(d) bendinde kâr dağıtımı yer almaktadır. Kâr payı avansı dağıtımı yetkisi de genel kurulun devredilemez yetkilerindendir ${ }^{27}$. Avans Dağıtımı Tebliği m 5'e göre kural olarak kâr payı avansı dağıtılabilmesi için hesap döneminde hazırlanan üç, altı ve dokuz aylık ara dönem finansal tablolarına göre kâr edilmiş olması gerekmektedir. Ancak bu şartların tamamı gerçekleşmiş olsa bile TTK Geçici m 13 yürürlükte kaldığı sürece genel kurulda, yönetim kurulunun kâr payı avansı dağıtmasına yönelik bir karar alınamayacaktır.

\section{c. Serbest Yedek Akçe}

Yedek akçeler genel anlamda tedbir amaciyla şirketlerin ekonomik zorluk çektiklerinde kullanabilmeleri için ayırdıkları birikimlerdir. Söz konusu birikimler şirketin devamlılığının sağlanması, alacaklıların haklarının korunması, iş hayatındaki belirsizliklerin azaltılması, gelecekteki zararların karşılanması ve istikrarlı kâr payı dağıtımının sağlanması amaçlarına hizmet eder ${ }^{28}$. Ayrıca şirketlerin kendi kendini finanse etmesi için önemli bir kaynak teşkil etmektedir. Yedek akçe ayrılması yoluyla şirketler yeni ortak bulmadan öz malvarlığını artırarak sermayenin korunması ve kuvvetlendirilmesini sağlar ${ }^{29}$.

TTK'ya göre serbest yedek akçeler, özel bir amaca özgülenmeyen yedek akçeler olup üç şekilde ortaya çıkar. Bunlar kanuni sermayenin veya çıkarılmış sermayenin

\footnotetext{
09.08.2012 tarihli ve 28379 sayılı Resmî Gazete'de yayımlanmıştır.

26 Veliye Yanlı, 'Kâr Payı Avansı Dağıtımı Hakkındaki Düzenleme (Sermaye Piyasası Kanunu'na Tabi Olmayan Şirketlerde' (Ankara 2014) Türk Ticaret Kanunu'na İlişkin İkincil Mevzuatın Değerlendirilmesi Sempozyumu 18 vd; Gürbüz Usluel (n 11) 108 vd; Üçışık ve Çelik, (n 10) 556 vd.

27 Gürbüz Usluel (n 11) 118; Yanlı Kâr Payı Avansı (n 26) 22; Üçışık ve Çelik, (n 10) 557.

28 Üçışık ve Çelik, (n 10) 183-184; Karslığlu (n 18) 202; Bilgin (n 10) 146; Çağırgan Tuncer ve Ulusoy (n 21) 1974.

29 Üçışı ve Çelik, (n 10) 188-189; Bilgin (n 10) 147.
} 
yarısını aşan kısmının oluşturduğu yedek akçeler (m 519/3), esas sözleşme gereği belli bir amaca tahsis edilmeden ayrılan yedek akçeler (m 521) ve genel kurulca ayrılmasına karar verilen yedek akçelerdir [m 523/2/(b)]. Kural olarak serbest yedek akçelerin şirket menfaati gözetilerek serbestçe kullanımı mümkündür ${ }^{30}$. Ancak yürürlükte kaldığı süre boyunca TTK Geçici m 13 ’te serbest yedek akçelerin dağıtımı da açıkça yasaklanmıştır.

\section{d. Kazanç Payı}

Y1llık kârdan alınan paylar TTK m 394 gereğince yönetim kurulunun mali haklarındandır. TTK m 511'e göre ise kazanç payı, yönetim kurulu üyelerine net kârdan kanuni yedek akçe için belirli ayrım yapıldıktan ve pay sahiplerine ödenmiş sermayenin yüzde beşi oranında veya esas sözleşmede öngörülen daha yüksek bir oranda kâr payı dağıtıldıktan sonra yapılabilen bir ödemedir. Dolayısıyla her iki hükmü birlikte değerlendirdiğimizde yönetim kurulunun mali haklarından olan kazanç payı, belirli dönemlerde ödenen sabit bir bedel olmayıp şirket kârlarından alınan paydır ${ }^{31}$.

TTK Geçici m 13'te açıkça kazanç payı dağıtımının da kısıtlandığına ilişkin bir ifade bulunmamaktadır. Ancak kazanç payının hukuki niteliği ve Geçici m 13 hükmünün amacı bir arada değerlendirildiğinde, kazanç payı dağıtımına ilişkin genel kurul kararlarının da Geçici m 13 kapsamında tartışılması gerektiği kanaatindeyiz.

\section{e. Borçlanma Yasağı}

Pay sahiplerinin şirkete borçlanması yasağı TTK m 358 ile hukukumuzda ilk kez düzenlenmiştir. Değişiklikten önceki hüküm, pay sahiplerinin iştirak taahhüdünden doğan borç hariç şirkete borçlanamayacağı, bunun istisnasının ise işletmesi dolayısıyla şirketle iş yapan pay sahiplerinin şirketin diğer müşterileri gibi şirketten mal alabilmesi şeklindeydi. Ancak TTK'nın yürürlüğe girmesinden önce, 26.12.2016 tarihli ve 6335 sayılı Kanunla bu hükümde değişiklik yapılmıştır. Söz konusu değişiklik sonucu daha kolay şartlar altında pay sahiplerinin şirkete borçlanması mümkün hale gelmiştir. Borçlanmanın şartları, ilgili pay sahibinin sermaye taahhüdünden doğan vadesi gelmiş borçlarını ifa etmiş olması ve şirketin serbest yedek akçelerle birlikte kârının geçmiş yıl zararlarını karşılayacak düzeyde olmasıdır. Dolayısıyla mevcut hükümde borçlanma yasağının kapsamı oldukça daraltılmış, bu iki şartın sağlanması halinde pay sahiplerinin şirkete borçlanması zaman ve miktar sınırı da olmaksızın serbest hale gelmiştir ${ }^{32}$.

\footnotetext{
Çağırgan Tuncer ve Ulusoy (n 21) 1993.

31 Kazanç payının huzur hakkı ve ücretten farklı bir nitelikte ödeme olduğuna ilişkin bkz Karslığlu (n 18) 217; Bilgin (n 10) 124,125 . Kazanç payının dağıtımına ilişkin ayrıntılı bilgi için bkz Veliye Yanlı, 'Yönetim Kurulu Üyelerine Sağlanacak Mali Haklar İle İlgili Bazı Değerlendirmeler' (2017) BATIDER C 3345 vd. Üçışık ve Çelik, (n 10) 338 vd.

32 Ayhan, Çağlar ve Özdamar (n 17) 281; Maddede buna ilişkin açık bir düzenleme bulunmamakla birlikte pay sahibi borçlanırken vade, faiz gibi konular bakımından üçüncü kişilerin borçlanmasına ilişkin şartlar göz önüne alınmalıdır. Konuya ilişskin bkz Kırca Şehirali Çelik ve Manavgat Cilt 2/2 (n 22) 680.
} 
TTK m 358'de değişiklik yapan maddenin gerekçesinde ortakların ve şirket yöneticilerinin acil kaynak ihtiyaçlarının şirket varlıklarından karşılanabilmesinin mümkün hale getirildiği, bu anlamda borçlanma yasağının yumuşatıldığı ancak kaldırılmadığı ifade edilmiştir ${ }^{33}$.

Şirkete borçlanma yasağının konusu nakit para, ayni malvarlığı gibi her türlü borç olabilir $^{34}$. Söz konusu yasağın uygulama alanına anonim şirketlerle birlikte TTK m 644'teki atıftan dolayı limited şirketler de girmektedir. Borçlanma yasağına tabi kişiler ise pay sahipleri ve intifa hakk1 sahipleridir ${ }^{35}$.

Pay sahibinin şirkete borçlanabilmesi için gerekli iki şartın; şirketin geçmiş yıl zararlarını karşılayacak şekilde yedek akçelerle birlikte kârının varlığı ve vadesi gelmiş sermaye borcunun bulunmaması olması, esasen şirkete borçlanma yasağının temelinde de sermayenin korunmas1 ilkesinin bulunduğunu gösterir ${ }^{36}$. Hükmün gerekçesinde de TTK m 358 ile pay sahiplerinin şirket varlıklarından sınırsız olarak borçlanmasına imkân tanınmadığı zira bu hususun TTK'nın temel ilkelerinden birisi olan sermayenin korunması ilkesine ters düşeceği ifade edilmiştir ${ }^{37}$.

TTK Geçici m 13 ile pay sahiplerinin borçlanmasını kısıtlayıcı herhangi bir düzenleme getirilmemiştir. Ancak bu hususun, Geçici m 13 ile ulaşılmak istenen amaca uygunluğu açısından bir değerlendirmenin yapılması gerektiği kanaatindeyiz.

\section{Zaman Bakımından Uygulanması}

7244 sayll Kanun m 17/1/(c) bendinde TTK Geçici m 13'ün yürürlük tarihi yayım tarihi olarak belirtilmiştir. Dolayısıyla bu düzenlemenin ilk fikrası 17.04.2020'den sonra genel kurul kararı alacak şirketler bakımından uygulanacaktır. Öte yandan ilgili düzenlemenin ikinci fikrası 2019yılı dönemine ilişkin dağıtım kararı almışancak henüz dağıtım yapmamış veya kısmi ödeme yapmış şirketleri de kapsamaktadır. Dolayısıyla icra edilmemiş genel kurul kararları açısından söz konusu hüküm geriye dönük uygulama alanı bulacaktır.

\footnotetext{
6335 sayılı Kanun m 15 gerekçesi.

34 Poroy, Tekinalp ve Çamoğlu (n 10) 356; Mustafa Çeker, 'Şirkete Borçlanma Yasăğ' (2012) Marmara Üniversitesi Hukuk Fakültesi Hukuk Araştırmaları Dergisi C 18 S 2663.

35 Ayhan, Çağlar ve Özdamar (n 17) 281; Emek Çolgar Toraman, Şirkete Borçlanma Yasağı (On İki Levha 2019) 144.

36 Ünal Tekinalp, 'Sermayenin Korunması İlkesi’ Prof. Dr. Rona Serozan'a Armağan Cilt 2 (Oniki Levha 2010) 1693; Kırca, Şehirali Çelik ve Manavgat Cilt 2/2 (n 22) 682; Pulaşlı (n 17) 354; Çeker (n 34) 663; Çolgar Toraman (n 35) 128; Ömer Korkut, 6102 sayılı Türk Ticaret Kanunu'na göre Anonim Şirketlerde Genel Kurul Kararlarının Butlanı (Karahan 2012) 132.

376335 sayılı Kanun m 15 gerekçesi.
} 
Buna göre Kanun'un yürürlüğe girdiği 17.04.2020 tarihinden önce dağıtım kararı almış ancak henüz tamamını dağıtmamış olan şirketler 2019 yılı net dönem kârının \%25'ini aşan kısma ilişkin ödemeleri 30.09.2020 tarihine kadar ertelemek zorunda olup Tebliğ m 4 hükmüne göre bu şekilde ertelenen ödemelere de faiz işletilmeyecektir ${ }^{38}$.

Benzer şekilde 17.04.2020 tarihinden önce yapılan genel kurulda yönetim organına kâr payı avansı dağıtımı yetkisi verilmişse avans ödemeleri de süre sonuna kadar ertelenecektir. Kanun'un yürürlüğe girdiği tarihten önce genel kurul kararı alıp ödemelerin tamamını gerçekleştirmiş olan şirketlere ise söz konusu düzenleme uygulanamayacaktır.

TTK Geçici m 13, 30.09.2020 tarihine kadar geçerli olmak üzere yürürlüğe girmiş olup belirlenen süreyi üç ay uzatmaya ve kısaltmaya Cumhurbaşkanı yetkilidir.

\section{Tebliğ ile Getirilen İstisnalar}

Tebliğ m 4 doğrultusunda net dönem kârının en fazla \%25'inin dağıtılabileceği ve geçmiş yıl kârlarının ve serbest yedek akçelerin dağıtılamayacağı kuralı TTK m 462'ye göre yapılacak iç kaynaktan sermaye artırımında uygulanmayacaktır. Esasen böyle bir istisna hükmü sayılmasaydı da TTK Geçici m 13’ün kâr dağıtımı yapılmaksızın iç kaynaklı sermaye artırımını engellemeyeceği sonucuna ulaşılmaktadır. Yine de uygulamada tereddüt oluşmaması adına, kârın şirket sermayesine eklenmesi durumunun açıkça istisna olarak sayılması düzenlemenin amacıyla uyumlu olmuştur.

Tebliğ m 5/1 ile kâr payı ve kâr payı avansı dağıtım kısıtlamasına ilişkin başka birtakım istisnalara yer verilmiştir. Buna göre;

a. Çalışanları COVID-19 salgını nedeniyle kısa çalışma ödeneğinden veya ücretsiz izne ayrllarak nakdi ücret desteğinden yararlanan şirketler ile hazine destekli kredi kefaleti kullanan ve kapanmamış kredi borç bakiyesi sunulan şirketler hariç olmak üzere genel kurulda en fazla 120.000 TL tutarında kâr payı dağıtımı kararı alan şirketler, b. Dă̆ıtımına karar verilen kâr payının en az yarısının başka bir sermaye şirketine olan sermaye taahhüt borcunun nakden ifasında kullanılacak olmasl şartıyla karar alan şirketler, c. Dağıtımına karar verilen kâr payının imzalanan kredi ve proje finansman sözleşmeleri kapsamında 30.09.2020 tarihine kadar muaccel hale gelecek yükümlülükleri ifasında nakden kullanılacak olması şartıyla karar alan şirketler

\footnotetext{
Hükmün genel olarak pay sahiplerinin meşru beklentilerine aykırı olduğu ve hukuki güvenliğe zarar verdiği, ikinci fikrasının ise mülkiyet hakkına ölçüllülük ilkesine aykırı bir müdahale oluşturduğu yönünde Aytuğar (n 3) 402-404. TTK Geçici m 13 düzenlemesi pay sahiplerinin mülkiyet hakkına bir müdahale olmakla birlikte bunun ölçülülük ilkesine uygun olup olmadığını ayrıntılı bir şekilde tartışmak gerekir. Bu hüküm ekonomik etkilerinin ne kadar süreceği bilinmeyen COVID-19 salgınından dolayı sermaye şirketlerinin uzun vadede ekonomik sıkıntılar yaşamasının önüne geçilmesi amacıyla getirilmiştir. Ayrıca bu hüküm geçici niteliktedir. Bu nedenle hükmün, dünya çapında beklenilmeyen olağanüstü gelişmeler dikkate alındığında, kabul edilebilir, amaca elverișli ve sermayenin korunması açısından gerekli olduğu söylenebilir. Ayrıca şirket kârının \%25'inin dağıtılabilmesi imkânı ve yasağın da belirli bir süreyle sınırlı olması sebebiyle düzenleme orantılılık ilkesiyle de uyumludur. Ancak bu dönemin şartlarının tahmin edilemeyecek bir şekilde e-ticaret, kargo gibi bazı sektörlerde faaliyet gösteren şirketlerin cirosunu ve dolayısıyla kârlılığını da artırmış olduğu da bir gerçektir. Buna rağmen hükmün muhataplarının tamamının menfaatleri birlikte değerlendirildiğinde, sınırlamanın kısa süreli olması ve dağıtılabilecek \%25'lik kâr payı da dikkate alındığında bahse konu kanuni düzenlemenin ölçülülük ilkesine aykırı olmadığı kanaatindeyiz.
} 
net dönem kârının en fazla \%25'inin dağıtılabileceği ve geçmiş yıl kârlarının ve serbest yedek akçelerin dağıtılamayacağı kuralından istisna tutulmuştur. Ancak m 5/1/(c) ile sayılan şirketler için tanınan istisna Tebliğ $\mathrm{m} \mathrm{5/2}$ düzenlemesiyle pay sahiplerinin ifa yükümlülüklerinin tutarı ile sınırlandırılmıştır.

Görüldüğü üzere TTK Geçici m 13 ile COVID-19 salgını nedeniyle şirketlerde nakdi sıkıntı yaşanmaması için tedbir amaçlı sınırlama getirilirken bu sınırlamanın ticari hayatı olumsuz etkilemesi muhtemel alanlara ilişkin de istisnalar tanınmıştır. Hükümde sayılan istisnalar kapsamında kalarak kâr payı dağıtımı yapacak şirketlerin bu hususu genel kurulda görüşmek için Tebliğ m 6'da sayılan belgelerle başvuru yaparak Bakanlıktan uygun görüş alması zorunludur.

TTK Geçici m 13'ün yürürlüğe girmesinden önce alınan ancak henüz icra edilmemiş ve istisna kapsamına giren genel kurul kararları için de Bakanlıktan uygun görüş alınması gerekip gerekmediği kamuoyunda tartışılmaktadır. İstisnalar dar yorumlandığı gibi ilgili istisna hükmünün uygulanmasına yönelik tamamlayıcı hükümlerin de aynı şekilde dar yorumlanması gerekir. Tebliğ m 6 hükmü incelendiğinde açıkça "5 inci madde uyarınca yapılacak kâr payı dağıtımlarının genel kurulda görüşülebilmesi için” Bakanlıktan uygun görüş alınması zorunlu tutulmuştur. Maddenin lafzından da anlaşılacağı üzere TTK Geçici m 13'ün yürürlüğe girmesinden önce yapılan genel kurullarda istisna kapsamına giren bir kâr payı dağıtımı kararı alınmış ise bu kararın uygulanması için daha sonra Bakanlıktan uygun görüş alınması gerekmediği kanaatindeyiz.

\section{TTK Geçici m 13'e Göre Genel Kurul Kararlarının Değerlendirilmesi}

\section{A. Genel Kurul Kararlarının Hukuki Niteliği}

Genel kurul kararı, hukuki sonuç doğuran bir irade beyanı olması nedeniyle bir hukuki işlem niteliğindedir. $\mathrm{Bu}$ nedenle hukuki işlemlerin geçersizliğine ilişkin müeyyideler genel kurul kararları için de uygulanabilir ${ }^{39}$. Dolayısıyla genel kurul kararlarının geçerliliği hem hukuki işlemlerin geçerlilik şartlarını düzenleyen genel hükümlere hem de TTK'nın özel hükümlerine tabi olacaktır ${ }^{40}$. Geçerli bir genel kurul kararından söz edebilmek için kararın toplantı ve karar yetersayılarına, kanuna, esas sözleşmeye, iyi niyet kurallarına uygun şekilde alınması ve tescile tabi kararların ticaret siciline tescil edilmesi gerekmektedir ${ }^{41}$.

\footnotetext{
39 Poroy, Tekinalp ve Çamoğlu (n 10) 588; Hasan Pulaşl1, 'Anonim Şirket Genel Kurul Kararlarının Sakatlı̆̆ı ve Müeyyidesi' (2013) Gazi Üniversitesi Hukuk Fakültesi Dergisi C XVII S 1-2 885 (“Pulaşll, Genel Kurul Kararları”); Fahrettin Önder, 'Yargıtay Kararları Açısından Limited Şirket Genel Kurul Kararlarının Hükümsüzlüğü' (2005) Dokuz Eylül Üniversitesi Hukuk Fakültesi Dergisi C 7 S 1103.

40 Poroy, Tekinalp ve Çamoğlu (n 10) 594.

${ }^{41}$ Pulaşlı Genel Kurul Kararları (n 39) 887.
} 


\section{B. Kanuna Aykırı Genel Kurul Kararlarına Uygulanacak Müeyyide}

Kanuna aykırı genel kurul kararlarının sakatlığının söz konusu olduğu durumlarda yokluk, butlan veya iptal olmak üzere üç farklı müeyyide gündeme gelebilir ${ }^{42}$. Bu çalışmada TTK Geçici m 13 bağlamında alınan ve kurucu unsurlar bakımından geçerli genel kurul kararları incelendiğinden yalnızca iptal ve butlan tartışma konusu yapilacaktır.

\section{1. İptal}

Yokluk ve butlan halleri dışında kalan genel kurul kararlarının sakatlığına uygulanan müeyyide iptal edilebilirliktir. Bu konu TTK m 445 ve m 446 hükümlerinde düzenlenmiştir. Buna göre iptal davası kanun veya esas sözleşme hükümlerine ve özellikle dürüstlük kuralına aykırı genel kurul kararları aleyhine açılabilmektedir ${ }^{43}$.

Müeyyidenin hangisi olacağına dair şüphe bulunması halinde kararın iptale tabi olduğunun kabul edilmesi gerekir ${ }^{44}$. Söz konusu kabul, butlanın ikincilliği ilkesi veya sakınma ilkesi olarak adlandırılan ve geçersizliğin sebebine ilişkin tereddüt yaşanması halinde hukuka aykırılığın çok ağır olmadığı görüşüne dayanmaktadır ${ }^{45}$. Geçici m 13'e aykırılık teşkil edebilecek bir genel kurul kararının iptal değil butlan kapsamında tartışılmasının isabetli olacağı kanaatindeyiz.

\section{Butlan}

Genel kurul kararlarının bir hukuki işlem olması nedeniyle söz konusu kararların butlanı da, hukuk düzeni tarafından öngörülen geçerlilik şartlarını içermemesi sebebiyle, başlangıçtan itibaren hüküm ve sonuç doğurmaması anlamına gelmektedir ${ }^{46}$. TTK m 447 veya 6098 sayılı Türk Borçlar Kanunu (TBK) m 27 hükümlerine aykırılık teşkil eden haller içeren genel kurul kararları batıldır.

TBK m 27 gereğince yasanın emredici hükümlerine, ahlaka, kamu düzenine ve kişilik haklarına aykırı ya da konusu imkânsız olan genel kurul kararları butlan müeyyidesine tabidir. TTK m 447'de de ayrıca örnekseme yoluyla üç butlan hali sayılmıştır ${ }^{47}$. TTK m 447'de açıkça sayılan butlan halleri TBK m 27'de sayılan butlan hallerinden sadece emredici hükümlere aykırılığa örnek verilebilir. Dolayısıyla özel

\footnotetext{
42 Dördüncü ihtimal olarak askıda hükümsüzlük konusunda ayrıntılı bilgi için bkz Erdoğan Moroğlu Anonim Ortakllkta Genel Kurul Kararlarının Hükümsüzlüğ̈̈ (8. Bask1, On İki Levha 2017) 32 vd.

43 İptal davasını açmaya m 446'da sayılan kişiler yetkilidir ve hak düşürücü süre karar tarihinden itibaren üç aydır. Genel kurul kararının iptali için mutlaka dava açılması gerekmekte olup iptal edilebilirlik itiraz veya def'i niteliğinde değildir. Hâkim tarafından re'sen dikkate alınmaz. Ayrıntılı bilgi için bkz Rauf Karasu, Anonim Şirketlerde Emredici Hükümler Illkesi (Güncelleştirilmiş 2. Bası, Yetkin 2015) 90 vd. Genel kurul kararının iptali, kararın mahkeme tarafından geriye dönük olarak ortadan kaldırılmasını sonucunu doğurur. Bkz Poroy, Tekinalp ve Çamoğlu (n 10) 598.

44 Poroy, Tekinalp ve Çamoğlu (n 10) 598; Pulaşlı (n 17) 360.

45 Bkz TTK m 447 Gerekçesi; aynı yönde bkz Kırca, Şehirali Çelik ve Manavgat Cilt 2/2 (n 22) 18.

46 Pulaşlı (n 17) 352.

${ }^{47}$ Ayrıntılı bilgi için bkz Kırca, Şehirali Çelik ve Manavgat Cilt 2/2 (n 22) 18 vd, 74 vd.
} 
nitelikteki bir düzenleme olan TTK m 447 hükmüne nazaran genel nitelikteki TBK m 27 aynı anda uygulanmaya devam edecektir ${ }^{48}$.

Butlan halleri çok geniş yorumlanmamalıdır. Çünkü batıl genel kurul kararlarının tespitinde butlanın ikincilliği ilkesi uygulanmakta olup ayrıca TTK m 445 karşısında TTK m 447 hükmü istisnai niteliktedir ${ }^{49}$. Nitekim TTK m 447 hükmünün gerekçesinde de bu husus şöyle açıklanmıştır:

"Sakınma, hükmün içerdiği bir ilkedir. Özellikle sözcüğ̈̈ bu sebeple sinırlayıcı bir işleve de sahiptir. Konusu itibarlyla bâtıl olan genel kurul kararları, bazı niteliklere sahip paysahipliği haklarını kaldıran veya sinırlandıran, anonim şirketin temel yapısını bozan ve sermayenin korunması ilkesine aykırı olan kararlara özgülenmiştir. ${ }^{50}$,"

Sermayenin korunması ilkesi, pay sahiplerinin, alacaklıların, şirket çalışanları ile genel olarak ekonomik hayat ve nihayetinde kamu menfaatinin korunmasını hedefler ${ }^{51}$. Sermayenin korunması, alacaklıların ve diğer menfaat sahiplerinin korunması yanında şirketin ekonomik istikrarını koruyabilmesi ve varlığının devam edebilmesi açısından hayati öneme sahiptir ${ }^{52}$ Sermayenin korunması ilkesi tüm sermaye şirketleri için geçerlidir ${ }^{53}$ ve bu ilkenin kapsamına kanuna aykırı her türlü ödeme ve malvarlığı çıkışının engellenmesi ile kanundaki şartlara aykırı kâr dağıtılmaması da girmektedir ${ }^{54}$. İhtiyatlılık politikası gereği çıkarılan ve dolayısıyla sermayenin korunmasına da hizmet eden Geçici m 13 ile getirilen sınırlamayı doğrudan ihlal eden bir genel kurul kararının TTK m 447/1/(c) bendi kapsamında butlana tabi olup olmadığının tartışılması gerekir. Öğretide görüş birliğiyle bu hükmün (c) bendinin ihlalinin mutlak butlanla sakat olduğu kabul edilmektedir ${ }^{55}$.

Yukarıdaki açıklamalar çerçevesinde TTK Geçici 13. madde ile getirilen dağıtım sınırlaması ve ortaya çıkabilecek ihtimalleri ayrı ayrı değerlendirmenin uygulamaya yol gösterici olacağı kanaatindeyiz.

\footnotetext{
Poroy, Tekinalp ve Çamoğlu (n 10) 597.

Bkz TTK m 447 Gerekçesi, Karasu (n 41) 70; Kırca, Şehirali Çelik ve Manavgat Cilt 2/2 (n 22) 17.

Bkz TTK m 447 Gerekçesi.

Bkz TTK m 447 Gerekçesi; Çolgar Toraman (n 35) 127; Korkut (n 36) 125.

Tekinalp Sermayenin Korunmast (n 36) 1693; Karslığlu (n 18) 201.

Tekinalp Sermayenin Korunması, (n 36) 1681.

4 Üçıșik ve Çelik, (n 10) 313; Korkut (n 36) 126.

55 Tekinalp Sermayenin Korunması, (n 36) 1698; Bu konudaki tartışmalar hakkında ayrıntılı bilgi için bkz Kırca, Şehirali Çelik ve Manavgat Cilt 2/2 (n 22) 73 vd; Moroğlu (n 42) 169 vd.
} 


\section{Geçici m 13'ün Yürürlük Tarihinden Önce Alınmış Olan Genel Kurul Kararları}

\section{1. İcra Edilmiş Genel Kurul Kararları}

TTK Geçici m 13 hükmünün yürürlük tarihi 17.04.2020 olup bu düzenlemenin icra edilmiş genel kurul kararları için geçmişe yürümesi söz konusu değildir. Bu nedenle 17.04.2020 tarihinden önce yapılan bir genel kurulda herhangi bir sınırlama olmaksızın kâr payı dağıtımı yapılması veya kâr payı avansı dağıtım yetkisi verilmesi mümkün olmuştur. Geçici 13. maddenin yürürlüğe girmesinden önce alınmış olan genel kurul kararları icra edilmişse, diğer bir ifade ile kararlaştırılan kâr paylarının tamamı dağıtılmışsa artık bahse konu işlemler açısından Geçici m 13 hüküm ve sonuç doğurmayacaktır.

\section{2. İcra Edilmemiş Genel Kurul Kararları}

Türkiye'de şirket genel kurulları çoğunlukla Mart ayının sonuna doğru yapılmaktadır. Bu sebeple de genel kurul kararlarının tescili ve icrası takip eden aylara sarkmaktadır. Dolayısıyla Geçici m 13 yürürlüğe girmeden önce alınmış bir genel kurul kararının icrasının yürürlük tarihinden sonraya kalması muhtemeldir. Bu ihtimali dikkate alan kanun koyucu da bu duruma ilişkin özel bir düzenleme yapmıştır.

\section{a. Kâr Payı Dağıtımı}

TTK Geçici 13. maddenin ikinci fikrasında yer alan özel düzenlemeye göre 17.04.2020 tarihi itibariyle henüz pay sahiplerine ödeme yapılmamışsa veya kısmi ödeme yapılmışsa, 2019 yılı net dönem kârının \%25'ini aşan kısma ilişkin ödemeler de düzenlemenin yürürlükte kaldığ1 süre boyunca ertelenecektir. Konuyu örnekler üzerinden şöyle açılayabiliriz:

(1) 17.04.2020 tarihinden önce yapılan genel kurulda 2019 net dönem kârının tamamının dağıtılmasına karar verilmiş olmasına rağmen 17.04.2020 tarihi itibariyle bu ödeme henüz yapılmamışsa kârın ancak \%25’i dağıtılabilecektir.

(2) 17.04.2020 tarihinden önce yapılan kısmi ödemeyle net dönem kârının yarısı dağıtıldıysa bu halde zaten $\% 25$ sınırından fazlası dağıtılmış olduğu için geri kalan kısım dağıtılamayacaktır.

(3) 17.04.2020 tarihinden önce yapılan kısmi ödemeyle net dönem kârının \%20'si dağıtılmışsa, ancak geri kalan \%5'lik kısım dağıtılabilecektir. 


\section{b. Serbest Yedek Akçe}

Tebliğ m 4/3'e göre 17.04.2020 tarihinden önce alınan ancak icra edilmeyen genel kurul kararlarında hesap döneminde zarar edilmiş olmasına karşın serbest yedek akçelerden dağıtım kararı alınmışsa, bu kararın da 17.04.2020 tarihi itibariyle icra edilmemiş olan kısmının dağıtımı ertelenmiştir. Buna göre hesap döneminde zarar etmemiş olan şirketler açısından serbest yedek akçeden dağıtım yapılması mümkündür.

\section{c. Kâr Payı Avansı}

17.04.2020 tarihinden önce alınan genel kurul kararında kâr payı avansı dağıtımı yetkisi verilmişse henüz dağıtılmamış avans ödemeleri de düzenlemenin yürürlük süresi boyunca ertelenmiştir ${ }^{56}$.

\section{d. Zamanaşımı ve Faiz}

Kâr payı alacağını talep hakkı, alacağın muaccel olmasından itibaren 5 yıllık zamanaşımına tabidir (TBK m 147). Geçici m 13/2 ile getirilen sınırları aşan ve hükmün yürürlükte kaldığı süre boyunca ertelenmiş olan ödemelerin talep edilmesine ilişkin olarak erteleme süresince zamanaşımının duracağını kabul etmek isabetli olacaktır ${ }^{57}$.

Ayrıca Tebliğ $\mathrm{m} 4$ doğrultusunda Geçici $\mathrm{m} 13$ gereği ertelenmiş ödemeler için faiz de talep edilemeyecektir.

\section{Geçici m 13’ün Yürürlük Tarihinden Sonra Alınan Genel Kurul Kararları}

Serbest yedek akçe, kâr payı avansı veya Geçici m 13 'te belirlenen sınırları aşan kâr payı dağıtımına ilişkin genel kurul kararlarının yanında bu hükme uygun olarak alınan genel kurul kararlarının da geçerliliği hakkında bazı tartışmalar mevcuttur ${ }^{58}$.

56 Tebliğ $\mathrm{m} 4 / 4$

57 Ali Dural, ‘COVID-19 Salgını Nedeniyle Türk Ticaret Kanunu'na 7244 Sayılı Kanunla Eklenen Geçici 13. Madde ile Sermaye Şirketlerinde Kar Dağıtımına Getirilen Sınırlamalar' (LexperaBlog, 20 Nisan 2020) https://blog.lexpera.com. tr/covid-19-salgini-nedeniyle-turk-ticaret-kanununa-eklenen-gecici-13-madde-ile-sermaye-sirketlerinde-kar-dagitiminagetirilen-sinirlamalar/ Erişim Tarihi 28 Nisan 2020

58 Paslı COVID-19 salgını ile mücadele kapsamında alınan sokağa çıkma yasağı, seyahat kısıtlaması gibi önlemlerin pay sahiplerinin genel kurul toplantısına katılımına olumsuz etki edebileceğini, böyle bir durumun da eşit işlem ilkesine aykırı olması ve genel kurulun usulsüz toplanması sonucunu doğurması sebebiyle alınan tüm genel kurul kararlarının geçersiz olacağını ifade etmektedir. Ayrıntılı bilgi için bkz Ali Paslı, 'Anonim/Limited Ortaklık Genel Kurul Toplantılarının 7244 sayılı Özel COVID-19 Kanunu Sonrasındaki Durumu: Sermaye Şirketlerindeki Ortakların Sağlığının Değeri Var Midir?' (Ticaret Kanunu.Net, 20 Nisan 2020) http://www.ticaretkanunu.net/ali-pasli-anonim-limited-ortaklik-genel-kurultoplantilarinin-7244-sayili-ozel-covid-19-kanunu-sonrasindaki-durumu-sermaye-sirketlerindeki-ortaklarin-sagliginindegeri-var-midir/ Erişim Tarihi 11 Mayıs 2020; Ali Paslı, 'COVID-19 Salgınının Anonim ve Limited Ortaklık Yıllık Olağan Genel Kurul Toplantılarına Etkisi: Güncel Koşullar Sürerken Genel Kurul Kararı Alınabilir Mi?’ (Ticaret Kanunu.Net, 24 Mart 2020) http://www.ticaretkanunu.net/covid-19-salgininin-anonim-ve-limited-ortaklik-yillik-olagan-genel-kurultoplantilarina-etkisi-guncel-kosullar-surerken-genel-kurul-karari-alinabilir-mi/ Erişim Tarihi 11 Mayıs 2020. 
Bu çalışmada Geçici 13. maddeye aykırılık teşkil edebilecek genel kurul kararları farklı ihtimaller dâhilinde incelenecektir.

\section{Kanuni Sınırı Așan Kısmın Dağıtılması Hali}

Geçici 13. maddenin emredici nitelikte olduğu ve esasen bir sermayenin korunması hükmü olduğu göz önüne alındığında kural olarak bu düzenlemeye aykırı kararların batıl olduğu kabul edilmelidir. Öğretideki bir görüş, Geçici m 13'e aykırı genel kurul kararının TTK m 1530/1 gereği batıl olduğunu ileri sürmüştür. Bu görüşe göre genel kurul kararları hukuki işlem niteliği taşıdığından ve Geçici m 13 de ticari bir hüküm niteliğinde olduğundan bu hükme aykırı genel kurul kararları TTK m 1530/1 kapsamında değerlendirilmelidir ${ }^{59}$.

Geçici 13. maddeye aykırı genel kurul kararlarına uygulanacak müeyyidenin dayanağının TTK m 1530 olup olamayacağı tartışmalıdır. Zira genel kurul kararlarının butlanı TTK m 447'de açıkça düzenlenmiştir. Dolayısıyla “Ticari hükümlerle yasaklanmış işlemler ile mal ve hizmet tedarikinde geç ödemenin sonuçlarl” başliklı TTK m 1530 hükmü, TTK'nın diğer hükümleri ve düzenlendiği yer ile metne dahil olan başlık hep birlikte değerlendirilmelidir. Hükmün lafzı tam açık olmamakla birlikte sistematik yorum açısından TTK 1530. madde hükmünün uygulama alanının esasen mal ve hizmet tedarikine ilişkin işlemler veya şartlarla sınırlı olması gerektiği kanaatindeyiz. TTK m 1530'un gerekçesinde, 6762 sayılı Kanun'un 1466. maddesinde öngörülen ticarî hükümlerde belirlenen sınırların aşılması halinde, yapılan sözleşmelerin tamamının geçersiz kılınması yerine, kısmî geçersizlik 
kavramının korunduğu ifade edilmiştir ${ }^{60}$. O halde TTK Geçici m 13 hükmüne aykırı bir genel kurul kararı söz konusu olduğunda, TTK m 1530’un karşılığı olan eski 6762 sayılı TTK m 1466'nın gerekçesindeki açıklamalar ile TTK m 447 hükmü birlikte dikkate alındığında genel kurul kararlarının butlanını özel olarak düzenleyen TTK m 447 çerçevesinde bir değerlendirme yapılarak bir sonuca varılmasının daha isabetli olacağı kanaatindeyiz ${ }^{61}$.

Geçici 13. maddenin yürürlüğe girmesinden sonraki tarihli bir genel kurul kararında hükümde getirilen sınırlamalara aykırı şekilde dağıtım yapılmasına karar verilir ve icra edilirse iki ihtimalin ortaya çıkması mümkündür. İlk olarak alınan genel kurul kararının bir bütün halinde batıl olduğu söylenebilir. Böyle bir yorum da esasen TTK m 447/1/(c) bendine ilişkin öğretinin görüşüne de uygundur ${ }^{62}$. İkinci olarak ise kararın yalnızca TTK Geçici m 13 ile getirilen sınırlamaya aykırı kısımları batıl kabul edilerek genel kurul kararının tamamının değil, yalnızca kâr payı dağıtımına ilişkin

60 TTK m. 1530'un karşılığı olan eski 6762 sayılı TTK m. 1466'nın gerekçesi dikkate alındığında 1530 hükmünün ilk cümlesinin amacıyla uyumlu olduğunu ve yeni olan 2. fikranın da esasen 1466'nın gerekçesinde ifade edildiğini söyleyebiliriz. 6762 sayılı TTK m 1466'nın gerekçesi şöyledir (http://www.ticaretkanunu.net/eski-ttk/ Erişim Tarihi 18 Ağustos 2020):

"MADDE 1466: Birtakım akitlerin veya hukuki muamelelerin yapılmalarının caiz olmadiğ veya birtakım hukuki muameleleri yapanların şu veya bu cezalara çarptırlacakları şeklinde hükümler derpiş eden kanunların tatbikatında bilhassa ilk zamanlarda birtakım tereddütler hissedilmektedir. Halbuki hususi hükümden aksi anlaşılmadıkça yapılması caiz olmadığ bildirilen veyahut sadece yapanların ceza göreceği bildirilen muamelelerin Borçlar Kanununun $20 \mathrm{ci}$ maddesi hükmünce bâtıl sayılmaları esastır. Birinci cümle bu noktada tereddütleri kaldırmaktadır. Gerçekten ticari olmiyan muameleler hakkinda da durum aynıdır ve bu cihet Borçlar Kanununun 20 nci maddesine ait ilmî eserlerden anlaşılmaktadır. Fakat burada sadece ticari hükümlerle konulan yasakların müeyyidesi için açı hüküm konulması kâfi görülmüss ve muhalif mefhum yoliyle ticari olmıyan muameleler sahasında aksi neticeye varılmaması için bu cihet burada belirtilmiştir.

Tasarının birinci maddesindeki tariften anlaşılacağı üzere bir ticari işletmenin yapacağı her hangi bir muameleyi ceza tehdidi altında bulunduran umumi veya hususi ceza kanunlarındaki hükümler dahi ticari hükümlerden sayllmak gerektir. Bu itibarla bir kanunun sadece ceza hükümlerini ihtiva ettiği ileri sürülerek ona aykırı olan muameleler hakkında tasarının bu maddesinin tatbik edilemiyeceği ortaya atılamaz.

Gerek harb ve fevkalâde hallerde gerekse iktisadi birtaklm sebeplerle, nizam altında tutulmak bilfarz bir narha tâbi tutulmak lâzımgelen akitlerde butlan hükmünün mutlak şekilde tatbiki, korunmak istenen kimselerin menfaatlerine asla uygun düşmez. Bu bakımdan bir akit uyarınca yerine getirilecek edalar meselâ teslim edilecek mallar veya ödenecek paralar hakkında en yüksek bir had tesbit edilmiş bulunmasına rağmen bu haddi aşkın olarak yapılan akitlerdeki edaların ancak haddi aşan kısmının hükümsüz sayılması ve fakat en yüksek hat içinde olan kısmın muteber tutulması kanun koyucunun en yüksek had koymayı derpiş ederek varmak istediği koruma gayesine uygundur. İkinci cümle hükmü, bu esası belirtmek üzere konulmuştur. Fakat hususi kanun hükmünden akdin tamamının bâtıl olacağı anlașılmakta ise bittabi bu madde hükmü yerine ö hususi hüküm tatbik olunacaktır.

Borçlar Kanununun 20 nci maddesinin son cümlesi hükmünce kanuna aykırı şartlar olmaksızın akdin yapılmıyacă̆ı kati olarak bilindiği takdirde akdin tamamen bâtıl sayılacağı kabul edilmiş olduğundan en yüksek haddi aşan akitlerde kanuna aykırı olarak en yüksek haddi aşan alacă̆ın alacakllsı bulunan kimsenin bu hükmü ileri sürüp akdin tamamiyle bâtıl olduğunu tesbit ettirmesi dahi mümkündür. Halbuki bu imkân en yüksek had hakkındaki kanun hükmünün konuluş gayesine aykırl düşer. Bu engeli de ortadan kaldırmak üzere son cümle hükmü konulmuş ve böylece ikinci ve üçüncü cümleler hükmünün tatbikinin önlenmesine meydan bırakılmamıştır."

${ }_{61}$ Bu yönde bkz Pınar ve Türkoğlu (n 3); Karababa (n 3). TTK Geçici m. 13 hükmüne aykırı genel kurul kararlarının sermayenin korunması ilkesine aykırılıktan bahisle batıl kabul edilmemesi gerektiği yönünde aksi görüşte Aytuğar (n 3) 405. Ancak sermayenin korunmasından amaç esasen şirket malvarlığının korunmasıdır. Bu nedenle ilkenin kapsamına kanuna aykırı her türlü ödeme ve malvarlığı çıkışının engellenmesi ile kanundaki şartlara aykırı kâr dağıtılmaması da girdiğinden [Tekinalp Poroy ve Çamoğlu (n 10) 316; Üçışı ve Çelik, (n 10) 313; Korkut (n 36) 126] bahse konu hükme aykırı bir uygulamanın da sermayenin korunması ilkesine aykırı olacağını söylemenin isabetli olduğu kanaatindeyiz.

62 Tekinalp Sermayenin Korunması, (n 36) 1698; Kırca, Şehirali Çelik ve Manavgat Cilt 2/2 (n 22) 73 vd; Moroğlu (n 42 ) 169 vd. 
\%25 sınırını aşan veya geçmiş yıl kârları, serbest yedek akçeler ve avans payı dağıtımı kısmının butlana tâbi olması sonucuna ulaşılabilir. Kanaatimizce ikinci ihtimalde k1smi butlan ${ }^{63}$ müeyyidesinin kabul edilmesi ve hukuki işlem lehine yorumla ${ }^{64}$ kararın kanuna uygun kısımlarının geçerli kabul edilerek sonuç doğurması, Geçici m 13 hükmünün amacına, genel kurul kararı alınması ve toplantının düzenlenmesi için gerçekleştirilmesi gereken prosedürlerin fazlalığı dikkate alındığında da usul ekonomisine daha uygun olacaktır. Ayrica COVID-19 tehlikesi halen devam ettiğinden 2020 yılı içinde yeni bir genel kurul toplantısı yapılmasının mümkün olamayacağı ihtimali de göz önüne alınmalıdır.

\section{Kanuni Sınırı Aşan Kısmın Dağıtılmaması Hali}

TTK Geçici m 13 kapsamında değerlendirilmesi gereken son ihtimal hükmün yürürlüğe girmesinden sonraki tarihli bir genel kurulda, hükümde belirtilen sınırları aşar şekilde karar alınması ancak kararın icra edilmemesidir ${ }^{65}$. 17.04.2020 tarihinden sonraki bir genel kurulda kanuni sınırı aşar şekilde karar alınmasına ilişkin iki farklı ihtimal gündeme gelebilir:

\section{a. Kanuni Sınırı Aşan Kısmın Derhal Dağıtılmasına Karar Verilmesi}

17.04.2020 tarihinden sonra alınan bir genel kurul kararında doğrudan TTK Geçici m 13 ile getirilen sınırlamalara aykırı şekilde dağıtım kararı alınmış ve kararın icrasına ilişkin herhangi bir erteleme öngörülmemiş olabilir. Böyle bir durumda sermayenin korunması ilkesine ilişkin emredici bir hükme aykırılık içeren kararın batıl olacağını kabul etmek gerekir. Ancak bu genel kurul kararının sadece TTK Geçici m 13'e aykırı kısımlarının, yukarıdaki açıklamalarımız dikkate alındığında, kısmi butlana tabi olması gerektiği kanaatindeyiz. Böyle bir yorumla genel kurul kararının kanuna uygun kısımlarının geçerli kabul edilmesi ve sonuç doğurması, ilgili hükmün gaî (amaçsal) yorumuna ve usul ekonomisine daha uygun olacaktır.

TTK hükümlerinde kısmi butlan kavramı yer almamakla birlikte TTK m 1 ile bu kanunun 4721 sayılı Türk Medenî Kanununun (TMK) ayrılmaz bir parçası olduğu düzenlenmiştir. TBK m 646 ise bu kanunun TMK'nın beşinci kitabı olup, onun tamamlayıcısı olduğunu hüküm altına almıştır. Dolayısıyla TTK'da hüküm bulunmayan hallerde TBK hükümlerine başvurulabileceği kabul edilmelidir. TBK m 27/2 ile sözleşmenin bir kısmının geçersiz olmasının diğer kısımları etkilemeyeceği ifade edilerek kısmi butlan düzenlenmiştir. Butlan sebebi sözleșmenin yalnızca bir bölümünün batıl olmasına sebep olurken sözleșmenin diğer kısımlarının geçerliliğini korumasında hukuka aykırılık bulunmuyorsa kısmi butlan kabul edilmelidir. Fikret Eren, Borçlar Hukuku Genel Hükümler (24. Bask1, Yetkin 2019) 336, 337. Kısmi butlanı düzenleyen TBK m 27/2 hükmünün genel bir hukuk ilkesinin uygulanması olduğu ve sözleşme dışındaki diğer hukuki işlemlere de uygulanması gerektiği hakkında bkz Veysel Başpınar, Borç Sözleșmelerinin Kısmi Butlanı (Adalet 1998) 49. $\mathrm{Bu}$ açıklamalar dikkate alındığında tıpkı sözleşme gibi bir hukuki işlem olan genel kurul kararları için de kısmi butlan kurumunun kıyasen uygulanması mümkündür.

${ }_{64}$ Kısmi butlan kurumuyla sözleșmenin bir kısmının geçerli kabul edilmesinin dayanağı sözleșme lehine yorum ilkesidir. Eren (n 63) 381.

${ }_{65}$ Kâr dağıtımına ilişkin genel kurul kararında dağıtım zamanın da tespit edilmesi gerektiği hakkında bkz İmregün (n 10) 434; Üçışık ve Çelik, (n 10) 295. 


\section{b. Kanuni Sınırı Aşan Kısmın Kısıtlama Sona Erdikten Sonra Dağıtılmasına Karar Verilmesi}

17.04.2020 tarihinden sonra alınan bir genel kurul kararında net dönem kârının \%25'inin derhal, geri kalan kısmının ve/veya serbest yedek akçeler ile kâr payı avansının ise TTK Geçici m 13 yürürlükten kalktıktan sonra dağıtılmasına karar verilmesi mümkündür. Kurul kararında bu durumun özel olarak belirtilmesi halinde Geçici m 13 sınırını aşan kısma ilişkin kararın geçerli olup olmayacağının incelenmesi gerekir.

Gaî(amaçsal) yorumilkesi gözönüne alındığında açıkçanet dönem kârının \%25'inin dağıtılmasına, bu miktarı aşan kısmın ve/veya geçmiş yıl kârları ile avans paylarının bu kanuni düzenleme ile öngörülen sürenin geçmesinden sonra dağıtılmasına ilişkin bir genel kurul kararının, TTK Geçici m 13'e uygun kabul edilmesi daha isabetli olacaktır $^{66}$. Kanaatimizce aksi yönde bir yorum, ilgili hükmün yorumlanmasında dikkate alınması gereken anayasaya uygun yorum ilkesiyle bağdaşmayacaktır. Zira \%25 sınırını aşan miktarın kanunun yürürlükten kalkmasından sonra dağıtılmasına yönelik kararın geçersiz sayılması irade özerkliğine ${ }^{67}$ ve pay sahiplerinin mülkiyet hakkına bir müdahale olup böyle bir müdahale ölçülülük ilkesine aykırılık teşkil edecektir.

Ölçülülük ilkesi, ulaşılmak istenen amaç için kullanılan aracın ölçülü olması gerektiği anlamına gelir ${ }^{68}$. TTK Geçici m 13 ile ulaşılmak istenen amaç; sermayenin korunması ve COVID-19 salgınının şirketlerde sebep olduğu finansman ihtiyacının karşılanması için nakit çıkışının sınırlandırılmasıdır. Hükümde öngörülen sınırı aşan ödemelerin kanunun yürürlükten kalkmasından sonra dağıtılmasına ilişkin bir genel kurul kararının, Geçici m 13 gereğince batıl kabul edilmesinin ölçülülük ilkesine uygun olmadığı düşüncesindeyiz.

Ölçülülük ilkesinin alt ilkeleri elverişlilik, gereklilik ve orantılılık ilkeleridir ${ }^{69}$. Kullanılan aracın amaca ulaşma noktasında hiçbir etkisi bulunmuyorsa aracın elverişli

66 Aksi yönde Dural (n 57). Dural, TTK Geçici m 13 birinci fikrasındaki düzenlemeye aykırı olarak maddenin yürürlüğe girdiği 17.04.2020 tarihinden sonra 2019 faaliyet yılına ilişkin genel kurullarda net kârın \%25'ini aşan oranda dağıtılmasına karar verilebileceği ve fakat kâr payı ödemelerinin ikinci fikradaki kurallara tabi olacağı şeklinde anlaşılmasının mümkün olmadığını ifade etmiştir.

67 Anayasa Mahkemesi'nin 05.03.2009 tarihli ve 27160 sayılı Resmî Gazete'de yayımlanan 2004/87 E ve 2009/5 K sayılı kararında irade özerkliği kavramı "Özel hukukta irade özerkliği, kişilerin yasal sınırlar içerisinde istedikleri hukuki sonuca bu yoldaki iradelerini yeterince açığa vurarak ulaşabilmelerini ifade etmektedir.” şeklinde açıklanmıştır. İrade özerkliği ile hukuki işlem ilişkisi için bkz Başpınar (n 63) 35, 36.

68 Metin Yüksel, 'Temel Hakların Sınırlandırılması ve Ölçülülük' (2017) SDÜHFD C 7 S 16.

69 Fazıl Sağlam, Temel Hakların Sinırlanması ve Özü (AÜSBF yayını 1982) 144; Yüksel (n 68) 7; Anayasa Mahkemesi’nin 31.05.2016 tarihli ve 29728 sayılı Resmî Gazete'de yayımlanan 2016/6 E ve 2016/37 K sayılı kararında ölçülülük ilkesine ilişkin "kanun koyucu, düzenlemeler yaparken hukuk devleti ilkesinin bir gereği olan ölçülülük ilkesiyle de bağlldır. Bu ilke ise "elverișlilik", "gereklilik" ve "orantılllık" olmak üzere üç alt ilkeden oluşmaktadır. "Elverişlilik", getirilen kuralın ulaşılmak istenen amaç için elverişli olmasını, "gereklilik", getirilen kuralın ulaşılmak istenen amaç bakımından gerekli olmasını, "orantılılık" ise getirilen kural ile ulaşılmak istenen amaç arasında olması gereken ölçüyü ifade etmektedir. Bir kuralda öngörülen düzenleme ile ulaşılmak istenen amaç arasında da "ölçülülük ilkesi” gereğince makul bir dengenin bulunması zorunludur." ifadeleriyle hüküm kurulmuş ve ölçülülük ilkesiyle alt ilkeleri tanımlanmıştır. 
olmadığ 1 kabul edilir ${ }^{70}$. TTK Geçici m 13 yürürlükten kalktıktan sonra dağıtım öngören bir genel kurul kararının batıl kabul edilmesinin hüküm yürürlükte kaldığı süre içinde şirketten nakit çıkışını sınırlama amacına hiçbir etkisi bulunmadığından elverişli bir araç olmadığı açıktır.

Ulaşılmak istenen amaca daha az müdahale eden bir başka araç ile ulaşmak mümkünse kullanılan aracın gerekli olmadığı sonucu ortaya çıkar ${ }^{71}$. Bu kapsamda bir değerlendirme yapmak gerekirse, söz konusu genel kurul kararı geçerli kabul edildiğinde de TTK Geçici $\mathrm{m} 13$ ile ulaşılmak istenen belli süre nakit sermayeyi şirkette tutma amacına ulaşılmaktadır. Zira kararın uygulanması halinde de TTK Geçici m 13 ile şirkette kalması amaçlanan sermaye şirketten çıkmamış olacaktır. Öyleyse \%25 sınırını aşan miktarın kanunun yürürlükten kalkmasından sonra dağıtılmasına yönelik kararın geçersiz sayılması amaca ulaşmada gerekli bir araç değildir.

Kanuni sınırı aşan kısımların kanuni kısıtlama kalktıktan sonra dağıtılması kararını geçersiz kabul etmenin orantılılık ilkesiyle de uyumlu olmadığı açıktır. Çünkü kullanılan aracın gerekli olmadığı tespit edildiği takdirde orantılılık denetimi yapılmasına da gerek kalmamaktadır ${ }^{72}$.

Yukarıdaki açıklamalar doğrultusunda, Geçici 13. maddenin sınırlarını aşan kısmın kanunun yürürlükten kalkmasından sonra dağıtımını öngören bir genel kurul kararının batıl kabul edilmesi ölçülülük ilkesine aykırı olacaktır. Netice itibariyle Geçici m 13'ün yürürlükten kalkmasından sonra hükümde belirtilen sınırı aşan kısmın dağıtımına ilişkin genel kurul kararının geçerli kabul edilmesinin anayasaya uygun yorum ilkesi gereğince isabetli olacağı kanaatindeyiz.

\section{Kazanç Payı ve Ortakların Borçlanmasına İlişsin Karar Alınması Hali}

Kazanç payı esasen belirli dönemlerde ödenen sabit bir bedel olmayıp TTK m 394 doğrultusunda şirket kârından alınan paydır ${ }^{73}$. Kazanç payının hangi şartlarda ödeneceği TTK m 511'de düzenlenmiştir. Kazanç payının istenebilir hale gelmesinin ön şartı genel kurul tarafindan önce kâr payı dağıtımı kararı alınmış olmasıdır ${ }^{74}$.

Daha önce de bahsedildiği üzere TTK Geçici m 13’ün amacı; şirket sermayesinin korunması ve şirketten nakit çıkışının sınırlandırılmasıdır. Her ne kadar Geçici m 13’te açıkça kazanç payından söz edilmese de kazanç paylarının serbestçe dağıtılmasının

\footnotetext{
Sağlam (n 69) 114,115; Yüksel (n 68) 8.

71 Sağlam (n 69) 115; Yüksel (n 68) 11.

72 Yüksel (n 68) 13.

73 Tekinalp (n 18) 277; Yanlı (n 14) 22; Ayhan, Çağlar ve Özdamar (n 17) 319; Hasan Pulaşlı 'Anonim Şirket Yöneticilerinin Haksız Yere Aldıkları Kazanç Payı ve Diğer Edimleri İade Yükümünün Türk ve İsviçre Hukuku Perspektifinden Değerlendirilmesi' Prof. Dr. Hikmet Sami Türk'e Armăgan (Turhan 2017) 590, 591 (Pulaşll, İade Yükümü). Kazanç payının niteliği konusundaki tartışmalar için bkz Bilgin (n 10) 124, 125.

74 Yanlı Mali Haklar (n 31) 48; İmregün (n 10) 424; Özer (n 14) 247.
} 
kabulü halinde hükmün amacına uygun bir sonuç doğmayacağı düşüncesindeyiz. Zira kazanç payının dağıtılacak kâr payı ile birlikte hesaplandığında net dönem kârının \%25'ini aşması halinde şirket kârının amaçlandığı şekilde şirket bünyesinde tutulması mümkün olmayacaktır.

Yönetim kurulu üyelerine dağıtılan kazanç paylarının TTK m 511 gereğince net dönem kârından dağıtılması sebebiyle TTK Geçici m 13 kapsamında sayılmasının evleviyetle kabulü gerektiği kanaatindeyiz. Zira Geçici m 13’te geçen kâr payı dağıtımı ifadesinin kazanç payını da kapsar şekilde geniş yorumlanması bu hükmün amacına uygun olacaktır. Geçici m 13 kapsamında dağıtımı ertelenen kâr payları için faiz istenemeyeceği göz önüne alındığında kazanç payının ertelenmesi halinde de faiz talep edilemeyeceği kabul edilmelidir. Ancak yabancı şirketler tarafından Türkiye'de TTK'ya göre kurulan şirketler ve bankalar haricinde diğer Türk şirketlerinde esas sözleşmede kazanç payı dağıtımı istisnai olarak görülmektedir. Kazanç payı dağıtımının öngörülmesi halinde de kâr payı dağıtımı içindeki oranı çok yüksek değildir ${ }^{75}$. Yine de net dönem kârının \%25'i dağıtılırken yönetim kurulunun kazanç payının da bu oranı aşmayacak şekilde hesaba dâhil edilmesinin gözden kaçırılmaması gerektiği kanaatindeyiz.

TTK Geçici m 13 kapsamında açıkça ifade edilmeyen ancak sermayenin korunmasına hizmet eden bir diğer husus da pay sahiplerinin şirkete borçlanması yasağına ilişkin TTK m 358'in uygulanmasının doğuracağı sonuçlardır. Geçici m 13 kapsamına pay sahibinin şirkete borçlanmasına ilişkin kararların girmediği açık olup esasen bu durum kanuni düzenlemede eksiklik olarak değerlendirilmiştir. Zira şirketin serbest yedek akçelerle birlikte kârı geçmiş yıl zararlarını karşılıyorsa, muaccel sermaye borcu bulunmayan her ortak şirkete borçlanabilecek olup bu yolla TTK Geçici m 13’ün bertaraf edilmesi ve salgın döneminde şirketten bir sınır olmaksızın nakit çıkışı sağlanması mümkündür ${ }^{76}$.

\section{Yönetim Kurulu Üyelerinin Kanuna Aykırı Genel Kurul Kararlarından Sorumluluğu}

Yönetim kurulu kendisine tanınan yetkiler dâhilinde karar almanın yanında genel kurul tarafından alınan kararları yürütmekle görevlidir ${ }^{77}$. Öğretide hakim görüşşirket ile yönetim kurulu üyesi arasındaki ilişkinin sözleşme ilişkisi olduğunu ve türünün

\footnotetext{
${ }_{5}$ Kar Payı Tebliği m 5/4'e göre esas sözleșmede yönetim kurulu üyelerine, kâr payı dağıtılması hususunda hüküm bulunmasına rağmen, kâr payına ilişkin olarak herhangi bir oran belirlenmemişse; bu kişilere dağıtılacak kâr payı tutarı, her durumda pay sahiplerine dağıtılan kâr payının dörtte birini aşamaz. Hukuka aykırı șekilde ödenen kazanç payının iadesine ilişkin ayrıntılı bilgi için bkz Pulaşlı İade Yükümü (n 73) 591 vd.

76 Dural (n 57).

77 Ersin Çamoğlu, 'Yönetim Kurulu Üyelerinin Genel Kurul Kararlarının İcrasından Doğan Sorumluluğu Konusunda Yeni Gelişmeler' (Aralık 1971) Banka ve Ticaret Hukuku Dergisi C 6 S 2284.
} 
vekalet sözleşmesi olduğunu kabul etmektedir ${ }^{78}$. Taraflar aksini kararlaştırmadığ sürece, bu sözleşme bir vekâlet akdi olarak nitelendirilir ${ }^{79}$. Yargitay uygulamasında da yönetim kurulunun şirketle arasında vekâlet ilişkisi olduğu ve vekil gibi sorumlu olunacağ 1 kabul edilmektedir ${ }^{80}$.

TTK m 369 ile yönetim kurulu üyelerinin özen ve bağl1lık yükümlülüğü düzenlenmiş, görevlerini tedbirli bir yöneticinin özeniyle yerine getirmeleri ve şirketin menfaatlerini dürüstlük kurallarına uyarak gözetmeleri gerektiği hüküm altına alınmıştır ${ }^{81}$.

TTK m 553 ise yönetim kurulu üyelerinin kanundan ve esas sözleşmeden doğan yükümlülüklerini kusurlarıyla ihlal ettikleri takdirde hem şirkete hem pay sahiplerine hem de şirket alacaklılarına karşı verdikleri zarardan sorumlu olacaklarını düzenlemiştir.

Yönetim kurulu üyelerinin şirkete karşı olan özen yükümlülüğünün bir sonucu yerine getirmekle yükümlü oldukları genel kurul kararının hukuka uygun olsa bile şirket menfaatlerine uygun olup olmadığını değerlendirmek ve bu konuda alınması gereken tedbirleri almaktadır ${ }^{82}$. Nitekim TBK hükümleri kapsamında da vekilin, kendisine verilen talimatın amaca ve vekâlet verenin menfaatine aykırılığına ilişkin vekâlet vereni uyarması gerektiği kabul edilmektedir ${ }^{83}$.

Genel kurul tarafından hukuka aykırı bir karar alınması durumunda ise söz konusu hukuka aykırı kararı yerine getiren yönetim kurulunun sorumlu olacağı kabul edilmelidir ${ }^{84}$. Zira yönetim kurulunun esasen alınan genel kurul kararının şirket menfaatine uygunluğundan önce hukuka uygunluğunu da denetlemesi gerekir ${ }^{85}$. Yönetim kurulunun, görevlerini tedbirli bir yöneticinin özeniyle yerine getirme yükümlülüğ̈̈, genel kurul kararının kanun emredici hükmüne aykırı olduğunu tespit etmesi halinde kararı uygulamaktan kaçınması ve gerekirse bu hususa ilişkin

\footnotetext{
78 ibid 287; Pulaşlı (n 17) 431; başka bir görüş ise sözleşmenin vekâlet sözleşmesine yakın olmakla beraber sui generis olarak nitelendirilmesinin daha uygun olduğu yönündedir. Bkz Ayhan, Çağlar ve Özdamar (n 17) 305. İsviçre hukukunda murahhas üye olmayan yönetim kurulu üyeleriyle şirket arasındaki ilişki, vekâlet benzeri isimsiz sözleşme (auftragsähnlicher Innominatkontrakt) olarak nitelendirilmektedir. Bu konuda ayrıntılı bilgi için bkz Peter Böckli, Schweizer Aktienrecht (Vol 2, Schulthess 2009) $1572 \mathrm{vd}$. Makale kapsamını aşmamak için buradaki tartışmalara değinilmemesi uygun görülmüştür.

79 Poroy, Tekinalp ve Çamoğlu (n 10) 389.

80 Yargitay Hukuk Genel Kurulu'nun 07.07.2010 tarihli, 2010/9-328 E ve 2010/370 K sayılı kararı; Yargitay 22. Hukuk Dairesi'nin 25.06.2014 tarihli, 2013/6333 E ve 2014/19169 K sayılı kararı (Kazanc1 veri tabanı).

81 Özen yükümlülüğü konusunda ayrıntılı bilgi için bkz Poroy, Tekinalp ve Çamoğlu (n 10) 240,241; Pulaşlı (n 17) 431; Hamdi Pınar, 'Şirketler Hukuku Açısından Anonim Şirket Yönetim Kurulu Üyelerinin Rekabet İhlallerinden Dolayı Sorumluluğu' (2009) BATIDER C XXV S $4390 \mathrm{vd.}$

82 Çamoğlu (n 76) 287; Mehmet Helvacı, Emin Çamurcu ve İsmail Türkyılmaz, 'Özellikle Anonim Şirket Açısından Şirket Menfaati Kavramı' Prof. Dr. Hamdi Yasaman'a Armağan (Seçkin 2017) 315.

83 Fikret Eren, Borçlar Hukuku Özel Hükümler (7. Baskı, Yetkin 2019) 742; Haluk Tandoğan, Borçlar Hukuku Özel Borç İlişkileri (Cilt 2, Vedat 2010) 445; Mustafa Alper Gümüş, Türk-İsviçre Borçlar Hukukunda Vekilin Özen Borcu (Beta 2001) 164,165 .

${ }^{84}$ Hukuka uyma yükümlülüğü kapsamındaki tartışmalar hakkında ayrıntılı bilgi için bkz Pınar (n 81 ) 385 vd.

85 Çamoğlu (n 77) 290.
} 
mahkemeye başvurmasını gerekli kılar ${ }^{86}$. Özen yükümlülüğüne ilişkin bu açıklamalar TTK m 626 gereğince ve m 644'teki atıf sebebiyle limited şirket müdürleri için de geçerlidir ${ }^{87}$.

Netice itibariyle TTK Geçici 13. maddeye aykırı bir genel kurul kararı alınması halinde bu kararın uygulanması yönetim organlarının özen ve şirket menfaatini gözetme yükümlülüğünün ihlali anlamına gelecektir. Dolayısıyla yönetim organının alınan genel kurul kararının Geçici m 13'te yer alan sınırlamayı aştı̆̆ için batıl olan kısımlarını yerine getirmemesi, daha açık bir ifadeyle \%25'i aşan kâr payını, serbest yedek akçeleri ve kâr payı avansını dağıtmaması gerekmektedir. Bu halde yönetim organının gerekiyorsa mahkemeye başvurarak söz konusu kararın Geçici m 13'e aykırı kısımlarının butlanının tespitini talep etmekle yükümlü olduğu kabul edilmelidirr ${ }^{88}$.

\section{Sonuç}

COVID-19 salgınının ticari hayata ilişkin olumsuz etkileriyle mücadele kapsamında sermaye şirketlerinin finansman ihtiyacının doğmaması, nakdi sermayesinin güçlü tutulması ve devamlılığının sağlanması için TTK'ya Geçici 13. madde eklenmiştir.

Geçici 13. madde yürürlükte kaldığ 1 sürece şirket sermayesinde bulunan serbest yedek akçelerin ve 2018 yılı ve öncesine ait geçmiş yıl kârlarının dağıttılması yasaklanmıştır. 2019 yılı net dönem kârının ise en fazla \%25'inin dağttılabileceği ve yönetim organlarına kâr payı avansı dağıtım yetkisi verilemeyeceği hüküm altına alınmıştır. İncelememizin konusu olan Geçici 13. maddenin kapsamı, uygulaması ve bu hükmün uygulanmasında ortaya çıkabilecek sorunlar hakkındaki görüş ve değerlendirmemiz kısaca şöyledir:

(1) Hükmün kapsamına sermaye şirketleri olan anonim, limited ve sermayesi paylara bölünmüş komandit şirketler dâhil olup hükümde kâr payı, serbest yedek akçe ve kâr payı avansı dağıtımına sınırlamalar getirilmiş̧ir. Ancak bu dağııım sınırlamalarına tabi olmayacak şirketler Geçici m 13 ve Tebliğ ile sınırlı sayıda belirtilmiştir.

(2) Geçici m 13'ün yayım ve yürürlük tarihi 17.04.2020 olup bu düzenlemenin ilk fikrası 17.04.2020 itibariyle henüz dağıtıma ilişkin genel kurul kararı almayan şirketler bakımından uygulanacaktır. Düzenlemenin ikinci fikrası ise 2019 yılı dönemine ilişkin dağıtım kararı almış ancak henüz dağıtım yapmamış veya kısmi ödeme yapmış şirketleri de kapsamaktadır. Düzenleme 30.09.2020 tarihine kadar yürürlükte kalacak olup Cumhurbaşkanı bu süreyi 3 ay uzatmaya ve kisaltmaya yetkilidir.

\footnotetext{
6 Çamoğlu (n 77) 291; Helvacı, Çamurcu ve Türkyılmaz (n 82).

87 Pulaşlı (n 17) 831 vd; Ayhan, Çağlar ve Özdamar (n 17) 530.

88 Dural (n 57); yönetim organının Geçici m 13 hükmüne uygun davranması gerektiği yönünde bkz Karababa (n 3).
} 
(3) 17.04.2020 tarihinden önce yapılan bir genel kurulda alınan kararların icrası tamamlanmışsa bu işlemler açısından Geçici m 13 hüküm ve sonuç doğurmayacaktır.

(4) 17.04.2020 tarihi itibariyle henüz net dönem kârı üzerinden kâr payı ödemesi yapılmamışsa veya kısmi ödeme yapılmışsa, 2019 yılı net dönem kârının $\% 25$ 'ini aşan kısma ilişkin ödemeler Geçici 13. maddenin yürürlükte kaldığı süre boyunca ertelenecektir. Ayrıca bu genel kurul kararında kâr payı avansı dağıtımı yetkisi verilmişse henüz dağıtılmamış avans ödemeleri aynı şekilde ertelenecektir.

(5) Geçici m 13 yürürlükte kaldığı süre boyunca ertelenmiş olan ödemelerin talep edilmesine ilişkin zamanaşımı duracak, ertelenmiş ödemeler için faiz de talep edilemeyecektir.

(6) Geçici m 13 ile düzenlenen dağıtım sınırını aşan ve 17.04.2020 tarihinden sonra alınan genel kurul kararlarına ilişkin müeyyidenin hukuki dayanăg 1 tartışmalıdır. Kanaatimizce Geçici m 13 sermayenin korunması ilkesine ilişkin bir düzenleme olduğundan bu hükme aykırı kararların TTK m 447 çerçevesinde batıl olup olmadığı incelenmelidir:

a. Kanaatimize göre 17.04.2020 tarihinden sonra alınan bir genel kurul kararının sadece TTK Geçici m 13'e aykırı kısımlarının kısmi butlana tabi olması gerekir. Zira bu şekilde genel kurul kararının kanuna uygun kısımlarının geçerli kabul edilerek sonuç doğurması, ilgili hükmün gaî (amaçsal) yorumuna ve usul ekonomisine daha uygun olacaktır.

b. 17.04.2020 tarihinden sonra yapılan bir genel kurulda net dönem kârının \%25'inin derhal, bunu aşan kısımların Geçici m 13 yürürlükten kalktıktan sonra dağıtılmasının kararlaştırılması da mümkündür. Bu karardaki Geçici m 13'te yer alan sınırları aşan kısmın batıl kabul edilmesinin ölçülülük ilkesine aykırılık teşkil edeceği, bunun yerine bu kararın geçerli kabul edilmesinin anayasaya uygun yorum ilkesi gereğince isabetli bir tercih olacağı düşüncesindeyiz.

(7) Yönetim kurulu üyelerine dağıtılan kazanç payları Geçici m 13’te doğrudan düzenlenmemiştir. Ancak hükmün asıl amacı şirket net dönem kârının \%25'inden fazlasının dağıtılmamasıdır. Kazanç paylarının da net dönem kârından dağıtılması sebebiyle Geçici m 13 kapsamına evleviyetle dâhil edilmesi gerektiği kanaatindeyiz.

(8) Pay sahiplerinin şirkete borçlanması yasağı da sermayenin korunması ilkesine hizmet eden ancak Geçici m 13 kapsamında sayılmayan eksik bir husustur. 
TTK m 385 doğrultusunda şirketin serbest yedek akçelerle birlikte kârı geçmiş yıl zararlarını karşıllyyorsa, muaccel sermaye borcu bulunmayan her ortak şirkete borçlanabilecek olup bu yolla Geçici m 13'ün bertaraf edilmesi ve salgın döneminde şirketten bir sınır olmaksızın nakit çıkışı sağlanması mümkün görünmektedir.

(9) Genel kurul tarafindan hukuka aykırı bir karar alınması durumunda bu hukuka aykırı kararı yerine getiren yönetim organı sorumlu olacaktır. Bu nedenle yönetim organının Geçici 13. maddeye aykırı şekilde net dönem kârının \%25'i aşan kâr payını, serbest yedek akçeleri ve/veya kâr payı avansını dağıtmaması gerekmektedir. Bu halde yönetim organı gerekiyorsa mahkemeye başvurarak söz konusu kararın Geçici m 13'e aykırı kısımlarının butlanının tespitini talep etmekle yükümlüdür.

Hakem Değerlendirmesi: Dış bağımsız.

Çıkar Çatışması: Yazarlar çıkar çatışması bildirmemiştir.

Finansal Destek: Yazarlar bu çalışma için finansal destek almadığını beyan etmiştir.

Peer-review: Externally peer-reviewed.

Conflict of Interest: The authors has no conflict of interest to declare.

Grant Support: The authors declared that this study has received no financial support. 


\section{Bibliyografya/Bibliography}

Akın M Y, 'Ticaret Bakanlığının 31.03.2020 tarihli Kâr Payı Dağıtımına İlişkin Yazısı Üzerine Düşünceler' (Ticaret Kanunu.Net, 9 Nisan 2020) (http://www.ticaretkanunu.net/murat-yusufakin-ticaret-bakanliginin-31-03-2020-tarihli-kar-payi-dagitimina-iliskin-yazisi-uzerinedusunceler/ E T 20 Nisan 2020).

Ateşağaoğlu E, Vergi Hukuku Bakımından Anonim Şirketlerde Kâr Payı Dağıtımı (On İki Levha 2012).

Ayhan R, Çağlar H ve Özdamar M, Şirketler Hukuku Genel Esaslar (2. Bask1, Yetkin 2020).

Aytuğar B, 'Anonim Şirketlerde Kar Payı ve Kar Payı Avansı Dağıtımı Hakkında 7244 Sayılı Kanun ile Öngörülen Tedbirler' (2020) İnönü Üniversitesi Hukuk Fakültesi Dergisi 11(2) 396-410.

Başpınar V, Borç Sözleşmelerinin Kısmi Butlanı (Adalet 1998).

Bilgin Y, Anonim Ortaklıklarda Kar Dağıtımı ve Kara Katılan Kişiler (Ankara İktisadi ve Ticari Bilimler Akademisi 1982).

Böckli P, Schweizer Aktienrecht (Vol 2, Schulthess 2009).

Çağırgan Tuncer S ve Ulusoy Y, 'Yedek Akçeler' (2017) DEÜ Hukuk Fakültesi Dergisi Prof. Dr. Şeref Ertaş'a Armağan C 19 Özel Sayı 1971-1996.

Çamoğlu, E, 'Yönetim Kurulu Üyelerinin Genel Kurul Kararlarının İcrasından Doğan Sorumluluğu Konusunda Yeni Gelişmeler' (1971) Banka ve Ticaret Hukuku Dergisi C 6 S 2 283-296.

Çeker M, 'Şirkete Borçlanma Yasağı' (2012) Marmara Üniversitesi Hukuk Fakültesi Hukuk Araştırmaları Dergisi C 18 S 2 659-670.

Çolgar Toraman E, Şirkete Borçlanma Yasağı (On İki Levha 2019).

Çonkar M H, 'Halka Açık Anonim Ortaklıklarda Kâr Payı Hakkına İlişkin Bazı Meseleler' (2017) İstanbul Hukuk Fakültesi Mecmuası C 75 S 2 659-680.

Dural A, 'COVID-19 Salgını Nedeniyle Türk Ticaret Kanunu'na 7244 Sayılı Kanunla Eklenen Geçici 13. Madde ile Sermaye Şirketlerinde Kar Dağıtımına Getirilen Sınırlamalar' (LexperaBlog, 20 Nisan 2020) (https://blog.lexpera.com.tr/covid-19-salgini-nedeniyle-turkticaret-kanununa-eklenen-gecici-13-madde-ile-sermaye-sirketlerinde-kar-dagitimina-getirilensinirlamalar/ E T 28 Nisan 2020).

Eren F, Borçlar Hukuku Genel Hükümler (24. Bask1, Yetkin 2019).

Eren F, Borçlar Hukuku Özel Hükümler (7. Bask1, Yetkin 2019).

Gümüş Mustafa A, Türk-İsviçre Borçlar Hukukunda Vekilin Özen Borcu (Beta 2001).

Gürbüz Usluel A E, Anonim Şirketlerde Pay Sahibinin Kâr Payı Alma Hakkı (Banka ve Ticaret Hukuku Araştırma Enstitüsü 2016).

Helvacı M, Çamurcu E ve Türkyılmaz İ, 'Özellikle Anonim Şirket Açısından Şirket Menfaati Kavramı' Prof. Dr. Hamdi Yasaman'a Armağan (Seçkin 2017).

İmregün O, 'Anonim Ortaklıkta Pay Sahibinin Kar Payı (Temettü) Hakkı' Prof. Dr. Ömer Teoman'a 55. Yaş Günü Armağanı C 1 2002, 413-343.

Karababa S, 'Koronavirüs (COVID-19) Pandemisi Nedeniyle 7244 sayılı Kanun'la Türk Ticaret Kanunu'nda Yapılan Değişikliklerin Sermaye Şirketlerinde Kâr Payı Dağıtımına Etkisi' (LexperaBlog, 30 Nisan 2020) (https://blog.lexpera.com.tr/koronavirus-covid-19-pandemisinedeniyle-7244-sayili-kanunla-turk-ticaret-kanununda-yapilan-degisikliklerin-sermayesirketlerinde-kar-payi-dagitimina-etkisi/ E T 28 Mays 2020).

Karasu R, Anonim Şirketlerde Emredici Hükümler İlkesi (Güncelleştirilmiş 2. Bası, Yetkin 2015). 
Karslığlu H, ‘Anonim Şirketlerde Kâr Payının Hesaplanması ve Dağıtım İlkeleri’ (2019) Ankara Barosu Dergisi C 77 S 3 181-227.

Kırca İ, Çelik F H ve Manavgat Ç, Anonim Şirketler Hukuku (Cilt 1, Banka ve Ticaret Hukuku Araştırma Enstitüsü 2013) (Kırca, Şehirali Çelik ve Manavgat, Cilt 1).

Kırca İ, Çelik F H ve Manavgat Ç, Anonim Şirketler Hukuku (Cilt 1, Banka ve Ticaret Hukuku Araştırma Enstitüsü 2016) (Kırca, Şehirali Çelik ve Manavgat, Cilt 2/2).

Korkut Ö, 6102 sayılı Türk Ticaret Kanunu'na göre Anonim Şirketlerde Genel Kurul Kararlarının Butlanı (Karahan 2012).

Moroğlu, Anonim Ortaklıkta Genel Kurul Kararlarının Hükümsüzlügü (8. Bask1, On İki Levha 2017).

Önder F, 'Yargıtay Kararları Açısından Limited Şirket Genel Kurul Kararlarının Hükümsüzlüğü' (2005) Dokuz Eylül Üniversitesi Hukuk Fakültesi Dergisi C 7 S 1 103-126.

Özer I, Türk ve Yabancı Hukuk Sistemlerinde Anonim Şirket Yöneticilerinin Mali Hakları (Adalet 2013).

Paslı A, 'Anonim/Limited Ortaklık Genel Kurul Toplantılarının 7244 sayılı Özel COVID-19 Kanunu Sonrasındaki Durumu: Sermaye Şirketlerindeki Ortakların Sağlığının Değeri Var Midır?' (Ticaret Kanunu.Net, 20 Nisan 2020) (http://www.ticaretkanunu.net/ali-pasli-anonimlimited-ortaklik-genel-kurul-toplantilarinin-7244-sayili-ozel-covid-19-kanunu-sonrasindakidurumu-sermaye-sirketlerindeki-ortaklarin-sagliginin-degeri-var-midir/ E T 11 Mayss 2020).

Paslı A, 'COVID-19 Salgınının Anonim ve Limited Ortaklık Yıllık Olağan Genel Kurul Toplantılarına Etkisi: Güncel Koşullar Sürerken Genel Kurul Kararı Alınabilir Mi?' (Ticaret Kanunu.Net, 24 Mart 2020) (http://www.ticaretkanunu.net/covid-19-salgininin-anonim-velimited-ortaklik-yillik-olagan-genel-kurul-toplantilarina-etkisi-guncel-kosullar-surerken-genelkurul-karari-alinabilir-mi/ E T 11 Mayıs 2020).

Pınar H, 'Şirketler Hukuku Açısından Anonim Şirket Yönetim Kurulu Üyelerinin Rekabet İhlallerinden Dolayı Sorumluluğu’ (2009) BATIDER C XXV S 4 369-405.

Pınar H ve Türkoğlu Ö, 'Sermaye Şirketlerinin Öz Kaynaklarını Korumasına İlişkin COVID-19 Önlemleri' (Magna Hukuk, 20 Mayıs 2020) (http://www.magnahukuk.com/sermayesirketlerinin-oz-kaynaklarini-korumasina-iliskin-covid-19-onlemleri/ E T 20 Mayss 2020).

Poroy R, Tekinalp Ü ve Çamoğlu E, Ortaklıklar Hukuku I (Güncellenmiş, Yeniden Yazılmış 14. Bas1, Vedat 2019).

Pulaşl1 H, Şirketler Hukuku Genel Esaslar (Adalet 2020).

Pulaşlı H, 'Anonim Şirket Genel Kurul Kararlarının Sakatlığı ve Müeyyidesi' (2013) Gazi Üniversitesi Hukuk Fakültesi Dergisi C XVII S 1-2 885-898 (Pulaşlı Genel Kurul Kararları).

Pulaşlı H, 'Anonim Şirket Yöneticilerinin Haksız Yere Aldıkları Kazanç Payı ve Diğer Edimleri İade Yükümünün Türk ve İsviçre Hukuku Perspektifinden Değerlendirilmesi' Prof. Dr. Hikmet Sami Türk'e Armağan (Turhan 2017) (Pulaşlı İade Yükümü).

Sağlam F, Temel Hakların Sinırlanması ve Özü (AÜSBF yayını 1982).

Tandoğan H, Borçlar Hukuku Özel Borç İlişkileri (Cilt 2, Vedat 2010).

Tekinalp Ü, 'Sermayenin Korunmasi İlkesi' Prof. Dr. Rona Serozan'a Armağan Cilt 2 (Oniki Levha 2010) 1681-1699 (Tekinalp Sermayenin Korunmasi).

Tekinalp Ü, Sermaye Ortaklıklarının Yeni Hukuku (Değişiklikler ve İkincil Düzenlemelerle Güncelleştirilmiş 4. Bası, Vedat 2015).

Üçışık G ve Çelik A, Anonim Ortaklıkta Finansal Tablolar Yedek Akçeler ve Kar Dağıtımı (On İki Levha 2018) 
Yanlı V, 'Kâr Payı Avansı Dağıtımı Hakkındaki Düzenleme (Sermaye Piyasası Kanunu'na Tabi Olmayan Şirketlerde' (2014) Türk Ticaret Kanunu'na İlişkin İkincil Mevzuatın Değerlendirilmesi Sempozyumu 13-15 (Yanlı Kâr Payı Avansı).

Yanlı V, 'Yeni Ticaret Kanunu ve Anonim Şirketlerde Kâr Dağıtımı' (Mart 2014) Banka ve Ticaret Hukuku Dergisi C 30 S 1 5-32.

Yanlı V, 'Yönetim Kurulu Üyelerine Sağlanacak Mali Haklar İle İlgili Bazı Değerlendirmeler' (2017) BATIDER, C 33 45-69 (Yanlı Mali Haklar).

Yüksel M, ‘Temel Hakların Sınırlandırılması ve Ölçülülük' (2017) SDÜHFD C 7 S 1 3-74. 